\title{
Above- and below-ground biodiversity responses to the prolonged flood pulse in central-western Amazonia, Brazil
}

\author{
Yennie K. Bredin ${ }^{1,2}$ | Laura L. Hess ${ }^{3}$ | Andressa B. Scabin ${ }^{4}$ | Micah Dunthorn ${ }^{5,6,7}$ (D) | \\ Torbjørn Haugaasen $^{1}$ | Carlos A. Peres ${ }^{4,8}$ | Henrik R. Nilsson ${ }^{9}$ (i) | \\ Alexandre Antonelli9,10,11 | Camila D. Ritter ${ }^{6,12}$ (1) \\ ${ }^{1}$ Faculty of Environmental Sciences and Natural Resource Management, Norwegian University of Life Sciences, Ås, Norway \\ ${ }^{2}$ Norwegian Institute for Nature Research, Oslo, Norway \\ ${ }^{3}$ Earth Research Institute, University of California Santa Barbara, Santa Barbara, California, USA \\ ${ }^{4}$ Instituto Juruá, Manaus, AM, Brazil \\ ${ }^{5}$ Natural History Museum, University of Oslo, Oslo, Norway \\ ${ }^{6}$ Eukaryotic Microbiology, University of Duisburg-Essen, Essen, Germany \\ ${ }^{7}$ Centre for Water and Environmental Research (ZWU), University of Duisburg-Essen, Essen, Germany \\ ${ }^{8}$ School of Environmental Sciences, University of East Anglia, Norwich, Norwich, UK \\ ${ }^{9}$ Gothenburg Global Biodiversity Centre, Department of Biological and Environmental Sciences, University of Gothenburg, Gothenburg, Sweden \\ ${ }^{10}$ Department of Plant Sciences, University of Oxford, Oxford, UK \\ ${ }^{11}$ Royal Botanic Gardens, Kew, Richmond, UK \\ ${ }^{12}$ Grupo Integrado de Aquicultura e Estudos Ambientais, Departamento de Zootecnia, Universidade Federal do Paraná, Rua dos Funcionários, Curitiba, PR, \\ Brazil
}

\section{Correspondence}

Yennie K. Bredin, Norwegian Institute for Nature Research, Oslo, Norway.

Email: Yennie.bredin@nina.no

Camila D. Ritter, Eukaryotic Microbiology, University of Duisburg-Essen, Essen,

Germany.

Email: kmicaduarte@gmail.com

Funding information

YKB was financed by the Norwegian University of Life Sciences (NMBU) as part of their PhD program in tropical ecology and an internal travel grant from NMBU. CDR was supported by the Alexander von Humboldt Foundation

\begin{abstract}
Amazonia encompasses extensive forests in areas that are periodically inundated by overflowing rivers. The inundation depth and duration vary according to the slope of the terrain and distance to major water bodies. This creates a flooding gradient from the lowest lying seasonally flooded forest up into the unflooded forest, which directly affects the biota. However, the effect of this gradient on soil organisms remains elusive. Here, we use DNA metabarcoding to estimate prokaryote and eukaryote diversity from soil and litter samples along the flooding gradient in centralwestern Amazonia using $16 \mathrm{~S}$ and $18 \mathrm{~S}$ gene sequences, respectively. We characterize the below-ground diversity and community composition based on amplicon sequence variants (ASVs). We examine relationships between the soil biota and the flooding gradient, soil properties, and above-ground woody plant diversity. The flooding gradient does not explain below-ground biodiversity, nor is below-ground diversity explained by the above-ground woody plant diversity. We uncover several taxonomic groups-such as Patescibacteria-not previously reported from Amazonian seasonally flooded forests. The flooding gradient and woody plant diversity partly explain the
\end{abstract}


community composition of soil bacteria. Although the effects of the flooding gradient, soil properties, and above-ground woody plant diversity are difficult to quantify, our results indicate that flood stress may influence below-ground bacterial community composition.

\section{KEYWORDS}

Amazonia, below-ground biodiversity, flooding gradient, Juruá, metabarcoding, seasonally flooded forests

\section{1 | INTRODUCTION}

Amazonia comprises the largest continuous tropical rainforest on Earth. Accounting for only $3.6 \%$ of the terrestrial global surface, Amazonia harbors some $10 \%$ of the world's known biodiversity (Maretti, 2014) and potentially hosts the largest Linnaean biodiversity knowledge deficit (Moura \& Jetz, 2021). This knowledge deficit is particularly acute for the below-ground biodiversity, which represents a large reservoir of the terrestrial biodiversity and fundamental ecosystem services that are key to the functionality of terrestrial ecosystems (Bardgett \& Van Der Putten, 2014; Pereira et al., 2018; Pietramellara et al., 2002). Traditional taxonomic methods cannot be readily used to quantify and study many groups of belowground biodiversity. Soil biodiversity therefore remains elusive and largely neglected in many global biodiversity assessments and policies (Cameron et al., 2018; Ritter et al., 2017). Fortunately, molecular approaches, including high-throughput sequencing (HTS) such as metabarcoding (Geisen et al., 2019), now enable us to address many previous obstacles to understanding the diversity and composition of soil communities (Cameron et al., 2019; Ritter, Zizka, et al., 2019; Tedersoo et al., 2014).

Globally, soil biota is recognized for its importance to soil health and in making nutrients available to the above-ground plant community. For instance, larger soil invertebrates are responsible for processing large amounts of detritus and making them available to other organisms (García-Palacios et al., 2013; Hättenschwiler \& Gasser, 2005). Similarly, micro-organisms are essential for nutrient cycling (Delgado-Baquerizo et al., 2020), and ectomycorrhizal fungi underlie ecosystem processes such as soil carbon cycling (Johnson et al., 2016). Research also demonstrates that below-ground biota may develop specialized mutualistic relationships with the above-ground plant community (Gahan \& Schmalenberger, 2014; Parniske, 2008). Such mutualistic relationships influence species diversity, ecosystem productivity, and community composition (Ferlian et al., 2018; Tedersoo et al., 2020; Teste et al., 2017; Van Der Heijden, 2002). Additionally, both soil biota and plants may affect the edaphic environment and species composition through the secretion of different chemical compounds that either inhibit or facilitate the distribution of particular species (Bennett et al., 2017; Eisenhauer et al., 2017). Thus, below-ground biota plays a key role in shaping the habitat of plants, and both below- and above-ground communities may interact to determine overall species compositions and diversity.
In hyper-diverse tropical regions such as Amazonia, there is very limited knowledge about the below-ground biodiversity and its interactions with the above-ground biota along gradients of resource availability and environmental stress. Species distribution patterns in Amazonia are complex, but forest dynamics, seasonality, topography, and the underlying geology seem to be main drivers of structural, compositional, and functional diversification (Baker et al., 2004; Higgins et al., 2015; Salovaara et al., 2004; ter Steege et al., 2006; Terborgh \& Andresen, 1998). For example, dry season length, clay content, soil phosphorus (P), calcium ( $\mathrm{Ca})$, magnesium $(\mathrm{Mg})$, and potassium (K) cation exchange capacity (CEC) appear to be important determinants of woody plant community composition (Sombroek, 2000; Toledo et al., 2017). In areas that flood, flood duration (i.e., the hydro-period) also seems indicative of woody plant community composition and alpha diversity (Alemán et al.; Arias et al., 2018; Assis et al., 2015a; Junk et al., 2012; Targhetta et al., 2015). Given the demonstrated implication of below- and above-ground community interactions for ecosystem functioning elsewhere (Wang \& Ruan, 2008), it would be important to understand how Amazonian belowground biodiversity relates to changes in these abiotic factors and the above-ground community. Such information could help us better predict and potentially mitigate adverse climate change disruptions on Amazonian ecosystem functions. Hence, this study focuses on below-ground community composition and alpha diversity along one of the most characteristic, complex environmental gradients in Amazonia, namely the seasonal flooding gradient.

Beyond the typical, unflooded tropical rainforests known as terra firme, Amazonia encompasses several other heterogeneous and distinct environments such as edaphic open areas associated with white sand soils as well as flooded forests (Myster, 2016). Flooded forests cover at least $9 \%$ of the basin (Hess et al., 2015) and grow in areas that are either permanently or periodically inundated by overflowing rivers, lakes, and perennial streams (Prance, 1996). These forests are characterized by a lower taxonomic diversity compared with unflooded terra firme forests (Haugaasen \& Peres, 2006; Myster, 2016; ter Steege \& Hammond, 2001). However, they have a characteristic fauna and flora often restricted to these environments (Myster, 2016; Ramalho et al., 2016). Flooded forests are thus crucial for the maintenance of regional biodiversity and climatic dynamics (Castello \& Macedo, 2016).

Two determinants are decisive for the extent of periodically flooded forests in Amazonia. The first is the uneven annual 
distribution of rainfall. In most of Amazonia, the rainy season is followed by a drier period lasting several months, but this is not synchronous across the basin. The second is the topography of the Amazon basin and its low-lying floodplains. Combined, these factors lead to an annual rise in fluvial discharge which causes an enormous flood pulse (Junk, 1989; Kubitzki, 1990) and gives rise to an aquatic and a terrestrial phase in the flooded areas. The inundation depth and duration of the floodwaters vary according to the slope of the terrain and with distance to the nearest perennial waterbody (Assis et al., 2015b; Wittmann et al., 2010). This creates a gradient in flood depth and duration from low-lying areas that flood to greater depths for longer periods of time to areas higher up in the terrain that rarely or never flood. This gradient directly affects the biota by generating thresholds for species establishment in that fewer species survive where the flooding is the most prolonged (Petit \& Hampe, 2006). Thus, it has been demonstrated that above-ground species diversity and composition in seasonally flooded forests change with variations in hydro-period and soil properties (Assis et al., 2019; Julião et al., 2018). Few studies have evaluated this difference in soil biota (Ritter, Zizka, et al., 2019), and to our knowledge, no study has yet examined the influence of the flooding gradient on forest soil biodiversity.

In this study, we use a metabarcoding approach to characterize the soil biodiversity along the flooding gradient of a seasonally flooded Amazonian landscape. More specifically, we investigate the diversity and composition of soil communities across four flood levels and explore whether, and if so how, the soil biota changes along the flooding gradient. In addition, by comparing the soil communities to the above-ground woody plant community, we examine the degree to which the above- and below-ground biodiversity are congruent. The results are discussed in relation to other studies and interpreted in light of differences experienced by seasonal flooding, soil characteristics, and above-ground woody plant diversity. Finally, we discuss some general implications to Amazonian biodiversity conservation.

\section{2 | MATERIALS AND METHODS}

\section{1 | Study area}

We conducted the study in the Uacari Sustainable Development Reserve (RDS Uacari) and nearby forests along the central reaches of the Juruá River, western Brazilian Amazonia (Figure 1). The climate of the region is hot and humid with a mean annual temperature of $\sim 27^{\circ} \mathrm{C}$, average annual rainfall of $\sim 3679 \mathrm{~mm}$, and a well-defined rainy season from December to May (Hawes \& Peres, 2016). We sampled above-ground woody plant communities and below-ground microbial communities at four different flood levels across the landscape which includes seasonally flooded, eutrophic forests known as várzea (VZ) and adjacent upland forest that does not flood on a seasonal basis. Generically, in Amazonia, "unflooded" forests are known as terra firme (TF). The "unflooded" Juruá forest that we sampled grows on Pleistocene floodplain sediments (i.e., paleo-várzea sediments; Assis et al., 2015b) abandoned by the meandering Juruá River and at higher elevations than the river's maximum flood level. This forest may therefore present soil of intermediate nutrient content compared with the eutrophic várzea soils and the typically heavily leached and nutrient-poor terra firme soils found on older geological formations. We sampled plots placed at least $800 \mathrm{~m}$ apart along the flooding gradient, with a maximum distance between upstream and downstream plots of $\sim 46 \mathrm{~km}$. Minimum and maximum plot distances from the main river channel were $\sim 1$ and $\sim 8 \mathrm{~km}$, respectively. The várzea communities were sampled during the 2016 and 2017 dry seasons, and the terra firme communities were sampled during the 2017 wet and dry seasons.

\section{2 | Determination of the hydro- topographic gradient}

To position the plots along the hydro-topographic gradient, we used inundation period mapped with multi-date ALOS-1 PALSAR satellite imagery (Fine-beam mode, resampled to $30 \mathrm{~m}$ ) freely available from the Alaska Satellite Facility Distributed Active Archive Center (https://search.asf.alaska.edu/). Juruá River stage levels at the Porto Gavião gauge (66.9 W, 4.88 S) were retrieved from Brazil's Agência Nacional de Águas (ANA; http://www.snirh.gov.br/hidroweb/serie shistoricas) for each of the 28 PALSAR imaging dates between 2007 and 2011 (9-10 dates for each of 3 PALSAR swaths covering the forest plots). Mean inundated months per year at the Porto Gavião river gauge were calculated from the 47-year river stage record, for the 28 stage levels corresponding to the PALSAR imaging dates. These long-term mean inundation periods were then assigned within isolines of floodplain inundation mapped on those 28 imaging dates, and the resulting inundation period classes were then grouped into the final four flooding classes. The 22 plots were grouped into the following four flood levels: (1) terra firme $=$ not seasonally flooded ( $n=6$ ); (2) high-várzea = 0-1 months/year ( $n=6$ ); (3) midvárzea $=2-4$ months/year ( $n=6)$; and (4) low-várzea = 5-12 months/ year $(n=4)$. Flood depth within each plot was determined by measuring the height of visible watermarks left on tree trunks within each plot after the most recent inundation peak. These measurements were made with a measuring tape to the nearest $\mathrm{mm}$.

\section{3 | Above-ground woody plant diversity}

We used 0.1 ha floristic plots $(100 \mathrm{~m} \times 10 \mathrm{~m})$ placed parallel to the main river channel to minimize variability in flood depth and duration within plots. We inventoried woody plant diversity as described in Bredin et al. (2020). Briefly, within each floristic plot, all trees, hemi-epiphytes, and palms $\geq 10 \mathrm{~cm}$ diameter at breast height (dbh)-as well as all highclimbing woody lianas $\geq 5 \mathrm{~cm}$ dbh-were measured and identified. Individuals that could not be determined to species level were sorted to morpho-species or, where applicable, higher taxonomic levels. For the following analyses, we only retained floristic data from plots where we also obtained information about substrate biota $(n=18)$. 


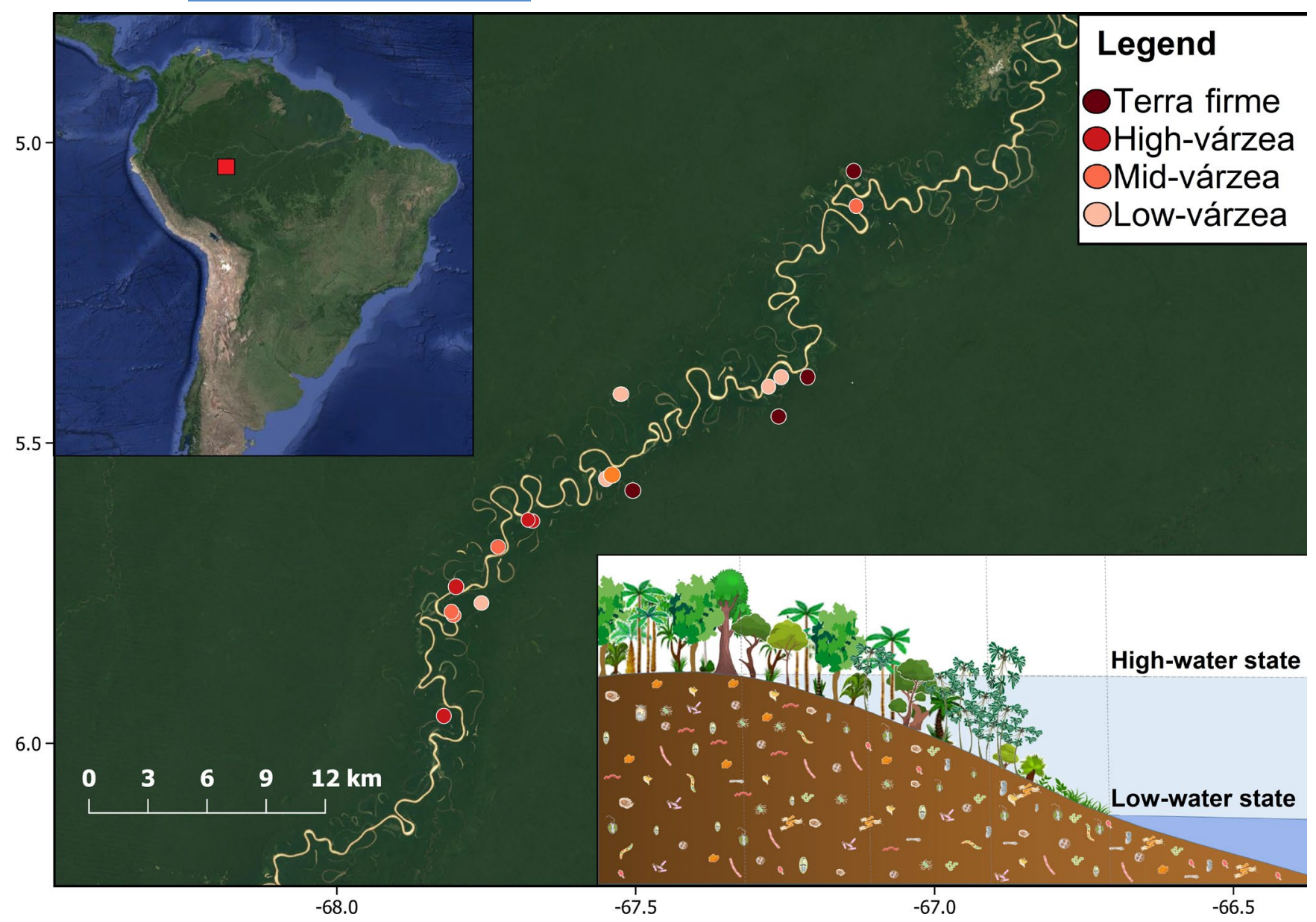

FIGURE 1 Sampling localities along the central Juruá River (main map) in the central-western Brazilian Amazon (upper left inset). The lower right inset shows a schematic cross-section of flood levels across the Juruá forestscape, with low- and high-water states separated by the dotted vertical lines. Terra firme forests are beyond the maximum flood levels of rivers, lakes, and perennial streams; high-várzea is located high up in the terrain and subject to shorter flooding periods (0-1 months/year); mid-várzea is subject to intermediate periods of flooding (2-4 months/year); and low-várzea is low-lying and subject to the longest flooding periods (5-12 months/year). Map created using QGIS3 software (Team, 2015a)

\section{4 | Below-ground microbial diversity}

To allow for direct comparisons with other metabarcoding studies of below-ground biodiversity, we used the sampling strategy described in Tedersoo et al. (2014) and Ritter, Zizka, et al. (2019). Briefly, we superimposed one circular substrate plot with a $28 \mathrm{~m}$ radius over each floristic plot (22 in total) by matching exactly the midpoints of the circular and floristic plots. Within each circular plot, we randomly selected 20 trees and collected litter and soil samples at the opposite sides of each stem. We first took a litter sample at every sampling point. After removing the leaf litter, we used a soil auger $(2.5 \mathrm{~cm}$ in diameter) to collect the top $5 \mathrm{~cm}$ of the soil. In total, we collected litter and soil at 40 points per plot. The samples were then mixed to provide one composite litter sample and one composite soil sample per plot. For each plot, soil samples were divided into two parts. The first part was sun-dried and transported to the EMBRAPA laboratory in Manaus (Brazil) where physicochemical analyses of granulation and nutrient content were performed following standardized procedures (Donagema et al., 2011; Ritter et al., 2018). The second part of the soil samples, as well as the litter samples, were dried with sterilized white silica gel 1-4 mm and transported to the University of Gothenburg, Sweden, for DNA extraction.

\subsection{DNA extraction and sequencing}

For total DNA extraction, we used the PowerMax ${ }^{\circledR}$ Soil DNA Isolation Kit (MO BIO Laboratories, USA) according to the manufacturer's instructions. We used $10 \mathrm{~g}$ (dry weight) from all soil samples and $15 \mathrm{ml}$ of the litter samples (corresponding to 3-10 g of dry weight litter, depending on texture and composition). We assessed DNA extraction quality and concentration in a Qubit $30^{\circledR}$ fluorimeter (Invitrogen, Sweden). The soil and litter samples from which DNA was successfully extracted were sent to Aimethods (Germany) for amplification and sequencing (with samples pooled at equal concentration). No successfully extracted samples were discarded for analysis. We targeted prokaryotes with the $\mathrm{V} 3-\mathrm{V} 4$ region ( 460 bases) of the $16 \mathrm{~S}$ rDNA gene using the forward primer (5'-CCTACGGGNGGCWGCAG-3') 
and the reverse primer ( $5^{\prime}$-GACTACH VGGGTATCTAATCC- $3^{\prime}$ ) from Klindworth et al. (2013). Eukaryotes were targeted with the $\mathrm{V} 7$ region of the $18 \mathrm{~S}$ rDNA gene using the forward and reverse primers (5'-TTTGTCTGSTTAATTSCG-3') and (5'-TCACAGACCTGTTATTGC-3') designed by Guardiola et al. (2015) to yield 100-110 bases long fragments. Both $16 \mathrm{~S}$ and $18 \mathrm{~S}$ fragments were sequenced with the Illumina MiSeq $2 \times 300$ platform. To check for sample contamination both from the indoor environment during the molecular analysis and cross-contamination among samples, we included negative controls in all steps: three for the extraction, two for the amplification, and two for the index ligation.

\subsection{Sequence analyses and taxonomic assessment}

We used the Cutadapt package (Martin, 2011) in Python v.3.3 (Van Rossum \& Drake, 2009) to remove primers. We then used the DADA2 package (Callahan et al., 2016) in R v. 4.0.2 (R Core Team, 2020) to quality filter reads, merge sequences, remove chimeras and to infer amplicon sequence variants (ASVs; Callahan et al., 2017). We excluded reads with ambiguous bases $(\max N=0)$. Based on the quality scores of the forward and reverse sequences, each read was required to have $<3$ or $<5$ errors, respectively ( $\operatorname{maxEE}=\mathrm{c}(3,5)$, truncQ $=2$ ). Therefore, ASVs were inferred for forward and reverse reads for each sample using the run-specific error rates. To assemble paired-end reads, we considered a minimum of 12 base pairs of overlap and excluded reads with mismatches in the overlapping region. Chimeras were removed using the consensus method of "removeBimeraDenovo" implemented in DADA2. We removed ASVs present in negative controls in a proportion larger than $40 \%$ of the reads for $18 \mathrm{~S}$ and all ASVs present in negative controls for $16 \mathrm{~S}$. We used the SILVAngs 132.1 reference database (Quast et al., 2012) for assessment of the taxonomic composition of the ASVs for both markers. The ASV reads by sample and taxonomic affiliation are provided in the Appendix S1 (for 16S) and Appendix S2 (for 18S). Additionally, we identified the functional guild for the ASVs assigned to the fungal kingdom using the FungalTraits database (Polme et al., 2020).

\section{7 | Statistical analysis}

We conducted all analyses in R v. 4.0.2 using R Core Team (2021). We used the tidyverse package v. 1.3.0 (Wickham, 2017) for data curation and ggplot2 v. 3.3.2 (Wickham, 2016), ggfortify v. 0.4.11 (Tang et al., 2016), gridExtra v. 2.3 (Auguie \& Antonov, 2016), and ggpubr v. 0.4.0 (Kassambara \& Kassambara, 2020) for data visualization (scripts in Appendix S3).

\subsection{1 | Soil properties}

To analyze the physicochemical profiles of the Juruá soils, we first normalized all soil variables to zero mean and unit variance using the "scale" function of vegan v. 2.4-3 (Oksanen et al., 2010). We then performed a principal component analysis (PCA) to reduce the number of soil property variables for subsequent analyses and visualize soil physicochemical properties in relation to flood level (i.e., terra firme, high-várzea, mid-várzea, and low-várzea). To test whether the Juruá terra firme soil (or paleo várzea sediments) indeed represented an intermediate nutrient content compared with eutrophic várzea soils and terra firme soils elsewhere in Amazonia, we ran an additional PCA following the same procedure as above but including soil property data from Ritter et al. (2018). These additional soil data include terra firme and várzea sites at Benjamin Constant, westernmost Brazilian Amazonia, and Caxiuanã, eastern Amazonia (Appendix S4 Table A1).

\subsection{2 | Alpha diversity}

As the richness estimates could be biased by rare ASVs (Haegeman et al., 2013), we calculated ASV Fisher's alpha diversity (i.e., the relationship between the number of ASVs in any given plot and the number of reads of each ASV) using the phyloseq R package v.1.34.0 (McMurdie \& Holmes, 2013) separately for the prokaryote (16S) and eukaryote (18S) datasets. We avoided using rarefied data because it is biased to detect differentially abundant species (McMurdie \& Holmes, 2014). Instead, we used the Hill numbers, which are considered the best approach for metabarcoding data (Mächler et al., 2020). However, to visualize our sequencing depths, we provide the rarefaction curves as Figure A1. For the woody plant communities, we used an abundance species matrix. We calculated the metrics within each plot and compared visually the non-normalized Fisher's alpha diversity indices of the below-ground biota and above-ground plant communities. We analyzed soil and litter Fisher's alpha diversity as a function of flood level (modeled as a continuous variable represented by the measured floodwater marks on trees, with terra firme being zero, and categorically according to forest type, i.e., flood level), soil properties (represented by PC1 of the soil PCA), type of sample (litter or soil), and above-ground Fisher's alpha diversity for woody plants. We normalized all the Fisher's alpha diversity estimates to zero mean and unit variance using the "scale" function in vegan.

To test for changes in below-ground alpha diversity relative to soil physicochemical properties, flooding, and the above-ground woody plant diversity, we defined a set of nine generalized linear models (GLM; Crawley, 2007) with Gaussian error distributions per dependent variable (i.e., prokaryote or eukaryote below-ground alpha diversity; Table 1). First, we checked for the distributions of residuals. We then constructed the model sets so that the first five models per set considered one explanatory variable each (1: flood level; 2: inundation depth of the last flood; 3 PC1 from the soil properties PCA; 4: type of sample [litter or soil]; or 5: woody plant Fisher's alpha diversity). Three additional models per set tested for (6) interaction terms among the flood levels and sample types, (7) flood levels and woody plant Fisher's alpha diversity, or (8) the 


\begin{tabular}{|c|c|c|c|c|c|}
\hline Marker & Model & $\mathrm{AlCc}$ & $\mathrm{dAICc}$ & df & Weight \\
\hline \multirow[t]{9}{*}{ Prokaryote (16S) } & $\sim 1$ & 89 & 15.9 & 2 & $<0.001$ \\
\hline & Flood level & 96.5 & 23.4 & 5 & $<0.001$ \\
\hline & Sample type & 75.5 & 2.3 & 3 & 0.2355 \\
\hline & Water mark & 89.7 & 16.5 & 3 & $<0.001$ \\
\hline & $\sim P C 1$ & 91.9 & 18.7 & 3 & $<0.001$ \\
\hline & $\sim$ PC1 * Flood level & 127.2 & 54 & 9 & $<0.001$ \\
\hline & $\sim$ Fisher div. & 85.6 & 12.5 & 3 & 0.0015 \\
\hline & $\sim$ Fisher div. ${ }^{*}$ Flood level & 113.3 & 40.1 & 9 & $<0.001$ \\
\hline & Fisher div. * Sample & 73.1 & 0 & 5 & 0.7625 \\
\hline \multirow[t]{9}{*}{ Eukaryote (18S) } & $\sim 1$ & 86.2 & 3.8 & 2 & 0.066 \\
\hline & Flood level & 94 & 11.6 & 5 & 0.0013 \\
\hline & Sample type & 82.4 & 0 & 3 & 0.4357 \\
\hline & Watermark & 89.2 & 6.8 & 3 & 0.0148 \\
\hline & $\sim P C 1$ & 91.9 & 9.4 & 3 & 0.0039 \\
\hline & $\sim$ PC1 * Flood level & 127.2 & 44.7 & 9 & $<0.001$ \\
\hline & Fisher div. & 83.6 & 1.1 & 3 & 0.2454 \\
\hline & $\sim$ Fisher div. ${ }^{*}$ Flood level & 111.7 & 29.3 & 9 & $<0.001$ \\
\hline & Fisher div. * Sample & 83.7 & 1.3 & 5 & 0.2328 \\
\hline
\end{tabular}

TABLE 1 Variables used in model selection with their respective delta $\mathrm{dAICc}$ and weight values

Note: The best fit model has a $\mathrm{dAICc}=0$ and is presented in bold as the alternative good models $(\mathrm{dAICc}=<2)$. The response variables are below-ground Fisher's diversity for prokaryotes $(16 \mathrm{~S})$ and eukaryotes (18S). The independent variables are flood level, sample type, water mark (measured floodwater marks on trees, with terra firme being zero), the PC1 from the soil physicochemical PCA analysis and the woody plant Fisher's diversity. Three models used combinations of PC1, flood level, Fisher's alpha diversity, and sample type as interacting variables.

flood levels and the soil PC1. The ninth model per set was defined as a constant, intercept-only model, that is, a null model with no explanatory variable. To select the models that best explained prokaryote or eukaryote below-ground alpha diversity, we used an information theory approach based on the Akaike information criterion (AIC; Akaike, 1974) and corrected AICs (AICc) for small sample sizes (Anderson \& Burnham, 2004). We based our model selections on the delta $\mathrm{AICc}(\mathrm{dAIC})$ that is the difference in $\mathrm{AICC}$ scores among models. The best model has a $\mathrm{dAIC} c=0$, but models with $\mathrm{dAIC} \leq 2$ were considered equally plausible. Were the best models defined as the constant, null models, this would imply that none of the explanatory variables included in the model sets could explain below-ground prokaryote or eukaryote diversity. The GLM analyses were performed using the vegan package, and model selection based on AICc was done using the bbmle package v.1.0.20 (Bolker \& Bolker, 2017).

\subsection{3 | Beta diversity}

We constructed two-dimensional non-metric multidimensional scaling (NMDS) ordinations of the abundance (reads) matrices of prokaryotes (16S) and eukaryotes (18S). We first transformed read counts using the "varianceStabilizingTransformation" function in DESeq2 v.1.30.1 (Love et al., 2014) as suggested by McMurdie and Holmes (2013). This transformation normalizes the count data with respect to sample size (number of reads in each sample) and variances based on fitted dispersion-mean relationships (Love et al., 2014). We then used the "metaMDS" function and Bray-Curtis distances in the vegan package to assess community dissimilarity among all samples in the NMDS. We used the "envfit" method in vegan to fit flood levels and sample types onto the NMDS ordination as a measure of the correlation among these factors with the NMDS axes. Additionally, we constructed two-dimensional non-metric multidimensional scaling (NMDS) ordinations based on the abundance data of the woody plants. Next, we used permutational analysis of variance (PERMANOVA) to assess whether flood level and sample type had any effect on community composition.

\section{3 | RESULTS}

We were able to extract, amplify, and sequence DNA for both prokaryotes (16S) and eukaryotes (18S) in 13 soil samples-17 litter samples for prokaryotes (16S), and 16 litter samples for eukaryotes (18S)-from a total of 18 plots. We obtained a total of 787,834 reads and 10,213 ASVs for the prokaryotes (16S). After removing the negative controls, we retained 757,827 reads and 9,337 ASVs. For the eukaryotes (18S), we obtained 616,237 reads belonging to 2267 ASVs and we kept 572,953 reads belonging to 2004 ASVs after removing the negative controls. See Appendix S4, Table A2 for the number of reads and ASV richness for each plot, and Appendices S5 and S6 for 
FIGURE 2 Principal component analysis (PCA) showing the clustering of inventory plots along the first two PCA axes in relation to the soil physicochemical composition. The red nuances and shape of the points indicate the flood levels: TF: Terra firme (triangles); HV, High-várzea (circles); MV, Mid-várzea (crosses); and LV, Low-várzea (squares)

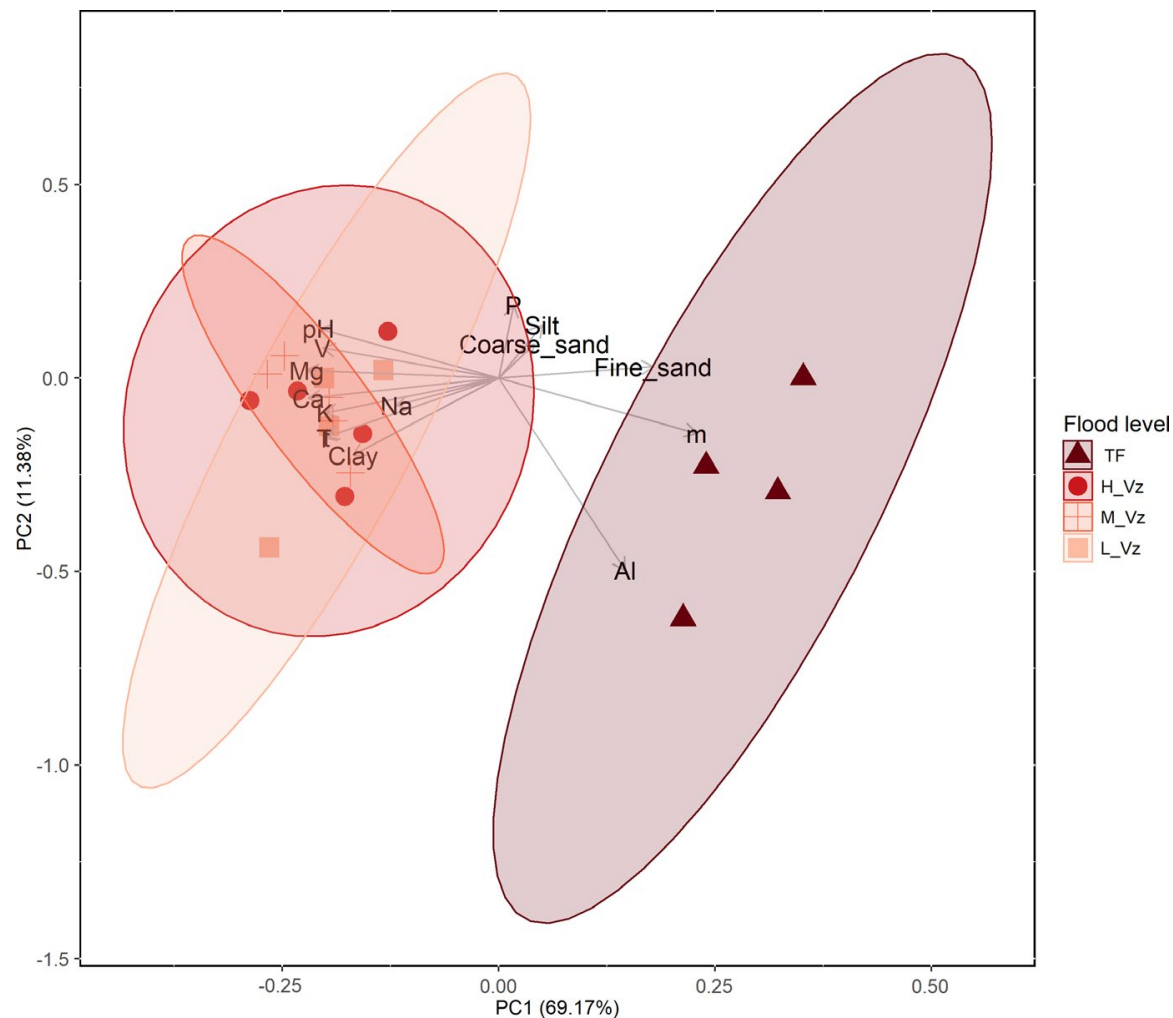

Krona charts of $16 \mathrm{~S}$ and $18 \mathrm{~S}$ taxonomic composition, respectively. The raw sequences are deposited in GenBank under (Bioproject PRJNA723037, BioSample SAMN18800640: Juruá (TaxID: 410658), accession SRA numbers: SRR14286278 - SRR14286277).

\section{1 | Soil properties}

The principal component analysis showed that the edaphic properties varied between terra firme and várzea plots (Figure 2; Appendix S4: Table A3). Soil physicochemical composition within the three várzea flood levels, however, largely overlapped (Figure 2). Várzea soils were dominated by clay and silt, whereas the terra firme soil was sandier (Figure 2). The terra firme soil was less fertile than the várzea soils, with lower concentrations of important nutrients such as potassium (K), calcium (Ca), and magnesium (Mg) (Figure 2). Compared with the terra firme and várzea soils from Benjamin Constant and Caxiuanã, the Juruá várzea is characterized by more exchangeable bases and clay and less phosphorous (P; Figure A2). The Juruá terra firme soil is placed between the Benjamin Constant and Caxiuanã terra firme soils (Figure A2).

\section{2 | Below-ground taxonomic composition}

The taxonomic composition of the prokaryote component shows that the groups with the highest number of ASVs were Alphaproteobacteria ( $25 \%$ of the taxa identified in our samples, equivalent to 2000 ASVs per flood level; Figure 3a; Appendix S4:
Figure A3A), Actinobacteria ( 23\%, average 1700 ASVs; Figure 3a; Appendix S4: Figure A3A), and Acidobacteria ( 18\%, average 1300 ASVs; Figure 3a; Appendix S4: Figure A3A). Among eukaryotes, Fungi had the highest number of ASVs ( 43\%, 600 ASVs), mainly Ascomycota and Basidiomycota (Figure 3b; Appendix S4: Figure A3B), followed by Cercozoa ( $18 \%, \sim 300$ ASVs; Figure 3b; Appendix S4: Figure A3B) and Ciliophora ( 15\%, 250 ASVs; Figure 3b; Appendix S4: Figure A3B). Based on the fungal taxonomic classification, we also retrieved information about fungal functional guilds. Most fungi were saprotrophs (Appendix S4: Figure A4). Other groups present were pathogens, parasites, mycorrhizal fungi, and unclassified fungi (Appendix S4: Figure A4).

\subsection{Alpha diversity}

We found that the best model to explain bacterial (16S) diversity included woody plant Fisher's alpha diversity and sample type (soil or litter) with an interaction effect between the two (Table 1), but only sample type was significant (Table 2). For eukaryotes (18S), three models had a delta AICc lower than 2 (Table 1). The first model $(\mathrm{dAICc}=0$ ) included only sample type, the second ( $\mathrm{dAICc}=1.1$ ) included only the woody plant Fisher's alpha diversity, and the third model $(\mathrm{dAICc}=1.3)$ included both woody plant Fisher's alpha diversity and sample type with an interaction effect between the two (Table 1). In all models, only sample type was significant (Table 2). Bacterial Fisher's alpha diversity was higher than the Fisher's alpha diversity of either below-ground eukaryotes or above-ground woody plants. In terra firme, bacterial diversity in 
(a)

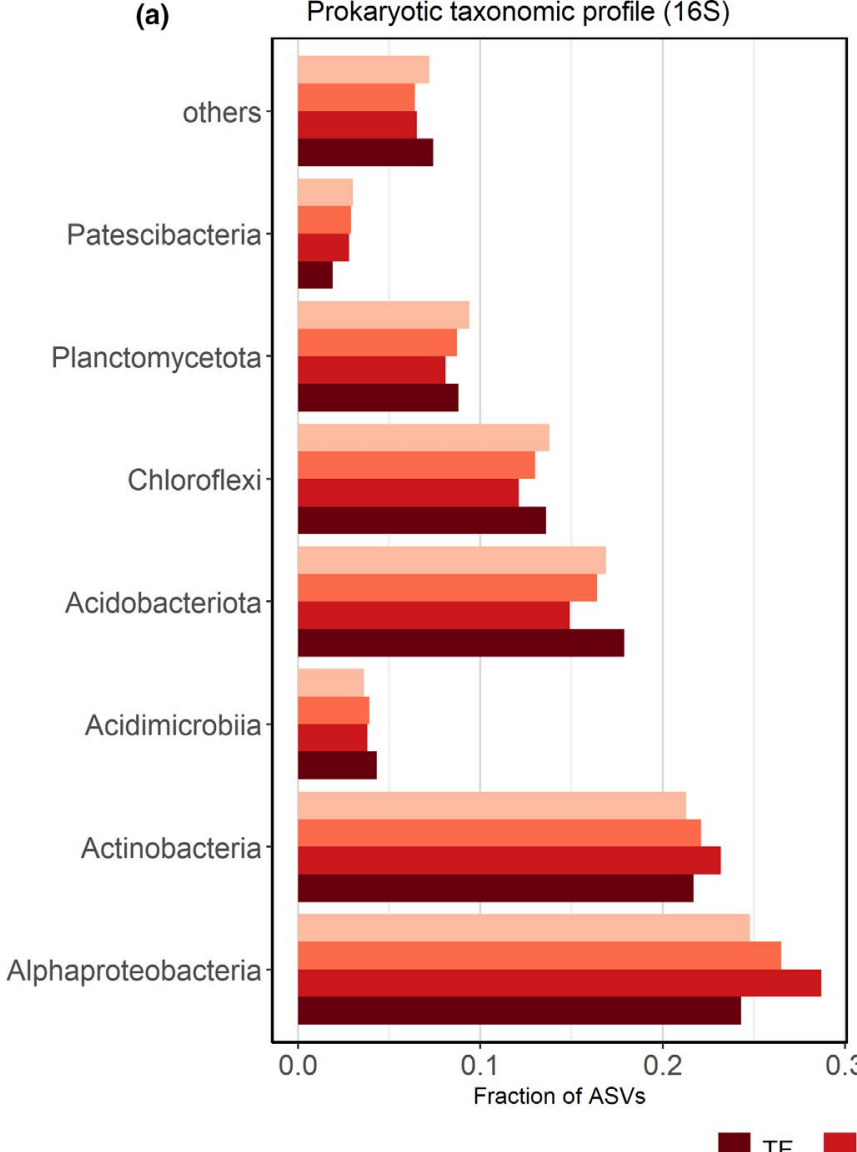

(b) Eukaryotic taxonomic profile (18S)

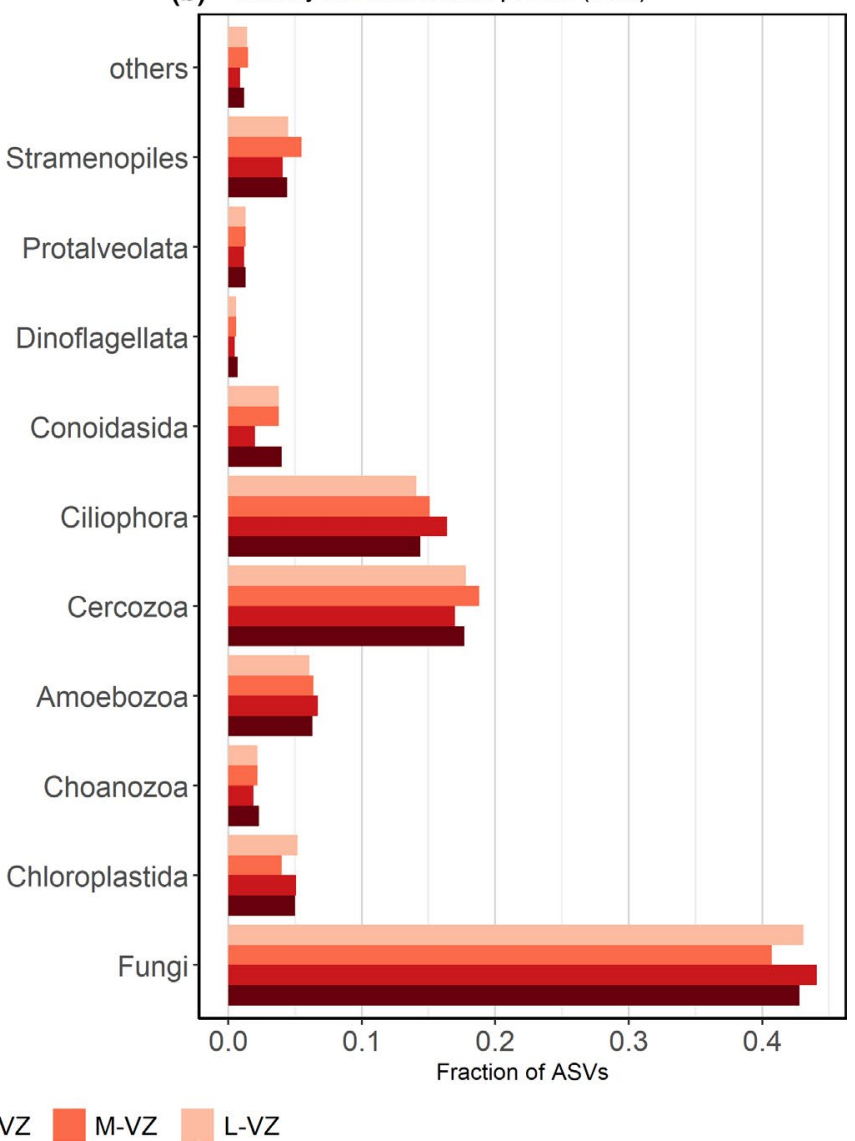

FIGURE 3 Fraction of ASVs by taxonomic group and flood level for (a) prokaryotes and (b) eukaryotes. Flood levels are TF, Terra firme; H-VZ, High-várzea; M-VZ, Mid-várzea; and L-VZ, Low-várzea

soil and litter, but not eukaryotes, appears to correlate with woody plant diversity. For the várzea plots, no significant pattern was observed (Figure 4).

\section{4 | Beta diversity}

Patterns of community composition were similar among plots across flood levels and sample types (litter and soil). For bacteria, there is a grouping of terra firme plots with some overlap with várzea plots (Figure 5a). No clear pattern was observed for soil eukaryotes (Figure 5b). For woody plant communities, there is a turnover in species compositions across different flood levels (Figure $5 \mathrm{c}$ ). The envfit test indicated a significant effect of flood level on both the prokaryote $\left(R^{2}=0.24 ; p=0.022\right)$ and woody plant $\left(R^{2}=0.48 ; p=0.003\right)$ communities, but not on soil eukaryotes $\left(R^{2}=0.14 ; p=0.28\right)$. The envfit test also indicated a significant effect of sample type on the prokaryote $\left(R^{2}=0.25 ; p=0.001\right)$ and eukaryote $\left(R^{2}=0.22\right.$; $p=0.006)$ communities. The PERMANOVA showed similar results, with a significant effect of flood level on both the prokaryote $\left(R^{2}=0.19 ; p=0.002\right)$, eukaryotes $\left(R^{2}=0.15 ; p=0.047\right)$ and woody plant $\left(R^{2}=0.25 ; p=0.001\right)$ communities. The sample type $R^{2}$ values were lower but still significant for the prokaryote $\left(R^{2}=0.06\right.$; $p=0.021)$ and eukaryote $\left(R^{2}=0.08 ; p=0.012\right)$ communities.

\section{DISCUSSION}

Our analyses have documented, to our knowledge for the first time, the degree to which soil and litter biota biodiversity are affected by the flooding gradient in central-western Amazonian forests of varying floristic diversity. We show a weak correlation between soil and litter community composition and inundation period but find that below-ground Fisher's alpha diversity cannot be explained by the flooding gradient. We also show that the edaphic properties differed between terra firme and várzea, but not among várzea forests along the flooding gradient.

\subsection{Flooding gradient and community composition}

Most ASVs occur throughout the flooding gradient (Appendices S1 and S2). This result was partly expected since the seasonal flood waters may carry DNA across the flooding gradient and thus mask any distributional differences among flood levels (Edwards et al., 2018). However, because such "shadow DNA" (i.e., DNA from nonresident organisms) may occur in lesser proportions than true community DNA, and because rare (low abundance) ASVs are more likely to be false positives than abundant ASVs (e.g., as an artifact 


\begin{tabular}{|lccccc} 
& & & \multicolumn{2}{l}{ Std. } & \\
& Coefficients & Estimate & Error & t value & $\operatorname{Pr}(>|t|)$ \\
\hline Prokaryote (16S) & (Intercept) & 0.6427 & 0.1815 & 3.54 & 0.00167 \\
& fisher.alpha & -0.2288 & 0.1947 & -1.175 & 0.2515 \\
& SampleSoil & -1.3463 & 0.2774 & -4.853 & $6.03 \mathrm{E}-05$ \\
& fisher.alpha:SampleSoil & 0.4439 & 0.2797 & 1.587 & 0.12566 \\
Eukaryote (18S) & (Intercept) & 0.43232 & 0.23733 & 1.822 & 0.0816 \\
& fisher.alpha & -0.03453 & 0.25159 & -0.137 & 0.892 \\
& SampleSoil & -0.89964 & 0.35607 & -2.527 & 0.0189 \\
& fisher.alpha:SampleSoil & 0.43738 & 0.36073 & 1.212 & 0.2376
\end{tabular}

TABLE 2 Estimated parameters (values estimated with standardized error, t value, and respective $p$-value) of the best fit model for $16 \mathrm{~S}$ and the third best fit model (that included the variables selected) for

Note: The response variables are below-ground Fisher's alpha diversity and (above-ground) woody plant Fisher's alpha diversity with an interaction term between the above-ground alpha diversity and sample type (soil or litter). Significant factors $(p<0.05)$ are marked in bold.

(a) Fisher's alpha diversity - 16S

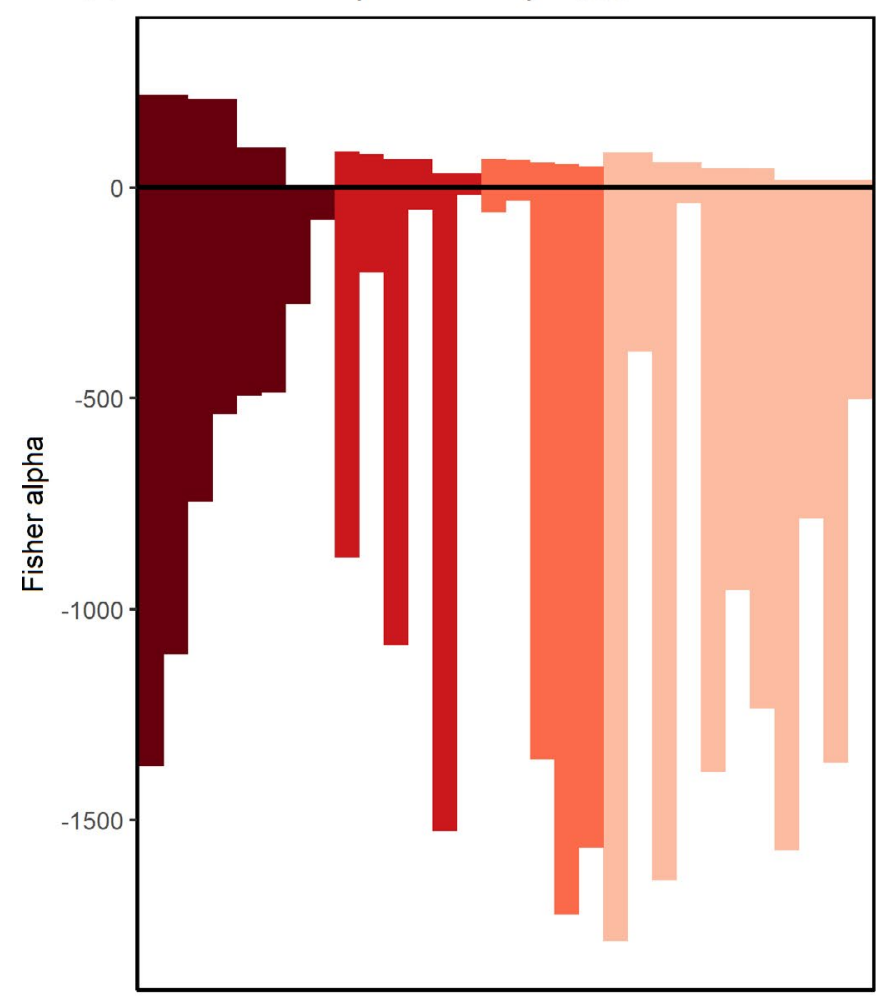

(b) Fisher's alpha diversity - $18 \mathrm{~S}$

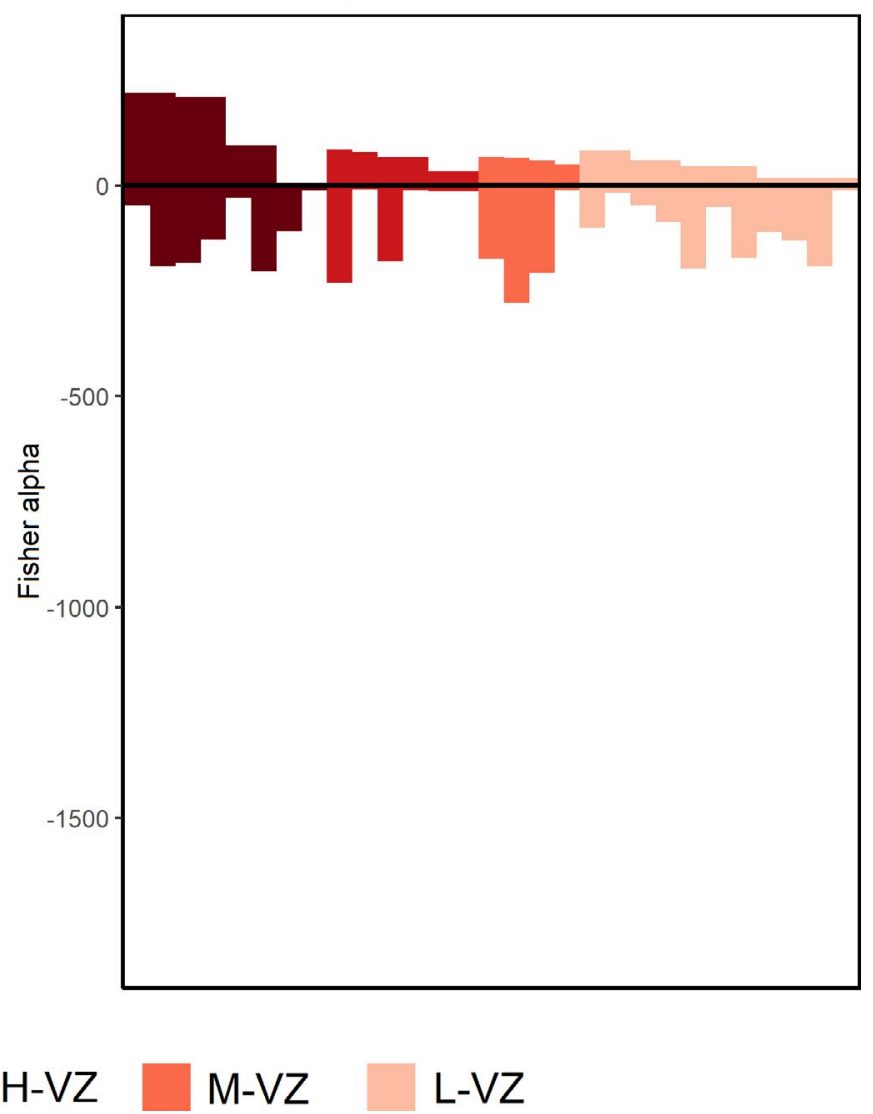

FIGURE 4 Above-ground woody plant Fisher's alpha diversity versus below-ground Fisher's alpha diversity of a) prokaryotic (16S) and b) eukaryotic (18S) organisms in Juruá litter and soil samples. Prokaryotic and eukaryotic diversity are shown in negative values. Woody plant diversity is shown in positive values. Flood levels are TF: Terra firme; H-VZ: High-várzea; M-VZ: Mid-várzea; and L-VZ: Low-várzea

of the amplification and sequencing processes), abundance data may be more informative than presence/absence analyses (Mächler et al., 2020; McMurdie \& Holmes, 2014). Considering the relative differences in abundances among ASVs across the flooding gradient, we could therefore detect a significant, albeit small, difference in below-ground community composition among flood levels. The low community turnover along the flooding gradient may however derive from a homogenizing effect of the flood pulse on the edaphic conditions among várzea flood levels and also due to large variation among samples within flood levels which may mask variation among the flood levels. Our results indicate that terra firme forest had different soil texture and fertility compared with várzea, but soil physicochemical properties were indistinguishable for the three várzea flood levels. 


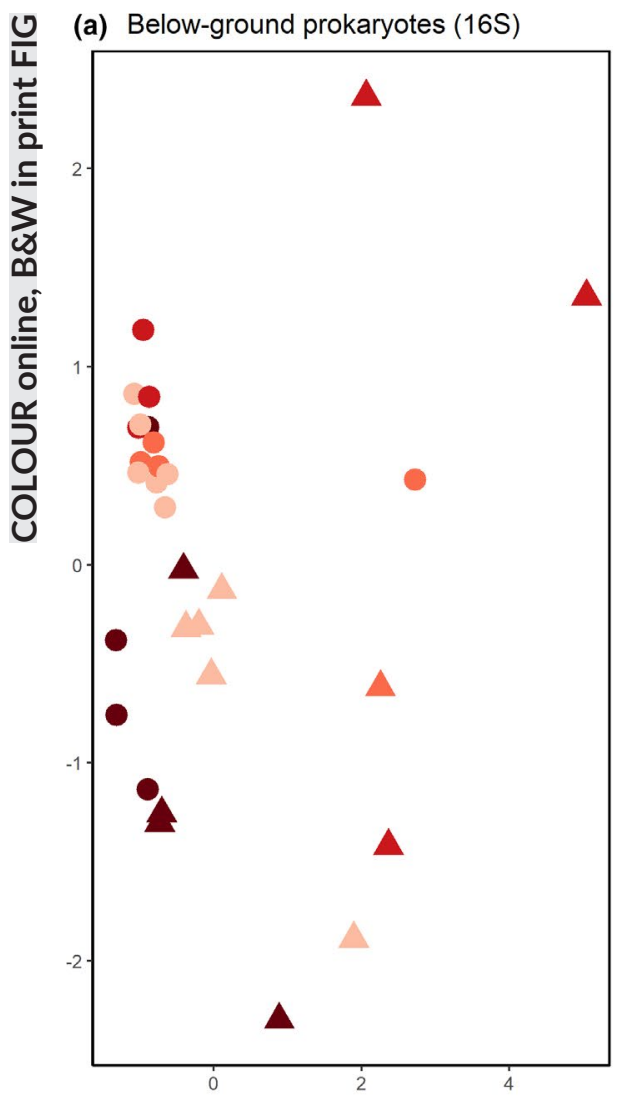

(b) Below-ground eukaryotes (18S)

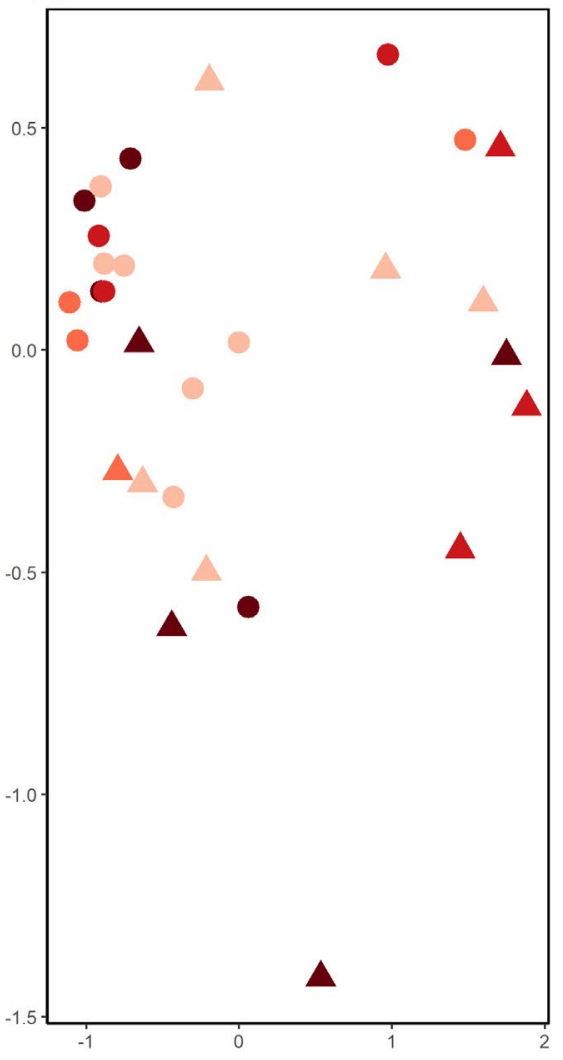

(c) Above-ground woody plant

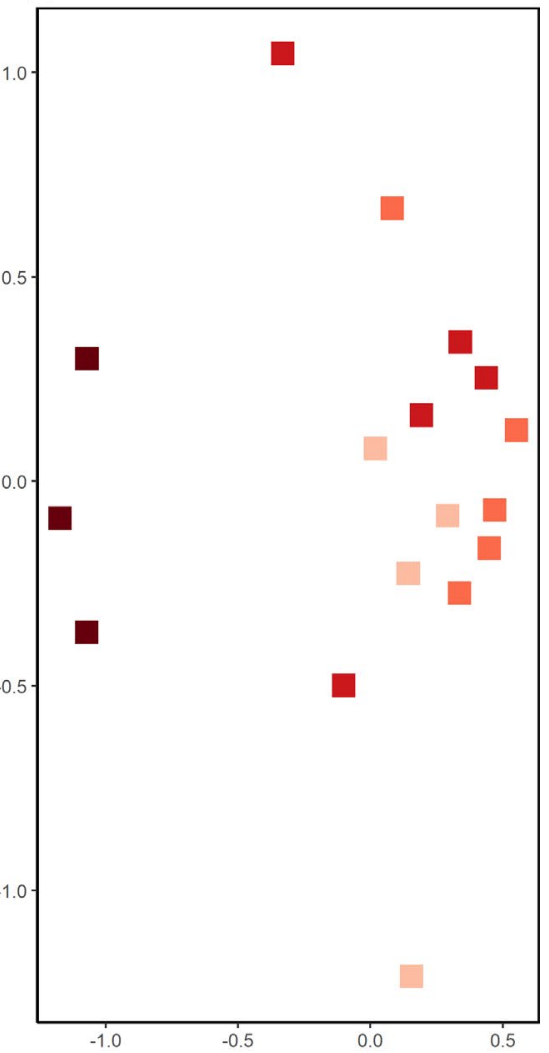

Flood class $\square$ TF $\quad \mathrm{H}-\mathrm{VZ} \square \mathrm{M}-\mathrm{VZ} \quad \mathrm{L}-\mathrm{VZ} \quad$ Sample $\quad$ Litter $\boldsymbol{\Delta}$ Soil $\boldsymbol{\square}$ Woody plants

FIGURE 5 Community structure in relation to substrate type and flood levels. Visualization of non-metric multidimensional scaling (NMDS) for (a) prokaryotes (16S), (b) eukaryotes (18S), and (c) woody plants using Bray-Curtis dissimilarity indices. Symbols represent different substrates (i.e., sample types) where filled circles = litter samples and filled triangles = soil samples. Colors represent the different flood levels: TF, Terra firme; H-VZ, High-várzea; M-VZ, Mid-várzea; and L-VZ, Low-várzea

The weak effect on the eukaryote (18S) community may be explained by a high range of mixed responses to the environmental gradient within the recorded taxa. For instance, soil fertility can change plant-mycorrhiza interaction effects from positive to negative (Johnson, 2010). Potentially, the soil physicochemical profile would thus be more important to the presence of mycorrhizal fungi than differences in hydro-period. At the level of other fungal functional guilds, there was also much overlap among flood-level communities. Only epiphytes and unspecified symbiotrophs were absent from the highest flood level (terra firme). Otherwise, all the functional guilds that we identified occurred throughout the flooding gradient. Whereas ectomycorrhizal fungi tended to be more abundant at lower flooding (high-várzea), lichenized and parasitic fungi seemed slightly more abundant at intermediate flooding (mid-várzea). Still, there were no substantial differences in abundances among fungal functional guilds across flood levels.

It is conceivable that protists may respond in different ways to the environmental gradient due to divergent lifestyles (parasitic to free living) and guilds (autotrophs to heterotrophs) (Adl et al., 2012; Geisen et al., 2018; Ritter, Machado, et al., 2020). Consequently, an effect of the flooding gradient on the protist community composition may be masked. In contrast, the Juruá bacterial community composition varied more among flood levels. This result may indicate that different groups of below-ground bacteria present specific tolerances to hydrological stressors and/or interdependencies with certain woody plant species. For instance, nodulation caused by nitrogen-fixing bacteria is more frequently observed in seasonally flooded forests compared with non-flooded forests (Parolin \& Wittmann, 2010). Thus, different groups of bacteria, for example, those that cause nodulation versus those that do not, may be favored to varying degrees along the flooding gradient and cause community composition to change.

\subsection{Above- versus below-ground diversity}

There was no relationship between above- and below-ground alpha diversity across the different flood levels. This mismatch could potentially be explained by a masking effect of the flood pulse, which may carry DNA fragments from non-resident organisms across the flood levels. Although the flood pulse may affect both below- and above-ground communities, our sampling design will report these 
effects differently. As we only sampled already established woody plants, the above-ground community has been filtered for species that are adapted to the flood level where they were recorded. In contrast, the DNA samples may include inactive spores of fungi and bacteria as well as DNA traces from organisms that would not survive at the sampled location, but that had been deposited there by the flood waters and which we detected through our metabarcoding analysis. Such trace DNA presumably occurs in lesser proportions than DNA from resident organisms, yet it may have added enough noise to mask any true distributional pattern of the below-ground diversity.

A lack of clear relationships between above- and below-ground biodiversity has previously been demonstrated globally (Cameron et al., 2019) and for other Amazonian areas (Ritter, Faurby, et al. 2019). However, for Amazonia this mismatch was partial. Although no correspondence was found between below-ground prokaryote or eukaryote alpha diversity and above-ground bird or tree alpha diversity across habitats, there was a gradual decrease in below- and above-ground alpha diversity from the west to the east across the Amazon basin (Ritter, Faurby, et al., 2019). Indeed, bacterial diversity appears to correlate with woody plant diversity in terra firme forests (Figure 3a), but we could not find a significant relationship perhaps due to the small sample size (four terra firme plots from which DNA was successfully extracted).

\section{3 | Edaphic properties}

Várzea edaphic properties in the Juruá differed from the other two Amazonian várzeas that we included in our additional analyses (Figure 2). For instance, the Juruá várzea was poorer in phosphorus $(\mathrm{P})$ and silt, but rich in magnesium $(\mathrm{Mg})$, calcium $(\mathrm{Ca})$, potassium $(\mathrm{K})$, and clay. This high-density clay content in the Juruá várzea may act as a physical barrier to water infiltration. On the other hand, clayey soils also have a high water-holding capacity (Hillel, 2013), which prevents them from drying out completely during the non-flooded periods. The high clay content additionally made Juruá várzea samples hard to collect and to break once dried. Possibly, this was the main factor that hindered DNA extraction in our study.

Compared with the terra firme soils, the Juruá várzea soils were more fertile, presumably due to the yearly inflow of nutrient-rich alluvial sediments by the Juruá River. Moreover, the Juruá terra firme soils presented similar edaphic properties to those of the terra firme forests in Benjamin Constant and Caxiuanã. This was unexpected since the terra firme forest that we sampled in the Juruá grow on paleo-várzea sediments (Assis et al., 2015b) and therefore presumably should have been relatively nutrient-rich compared with typically well-drained and heavily leached terra firme soils on older geological formations (Sombroek, 2000). However, these soils presented similar edaphic properties to those of the terra firme forests at Benjamin Constant and Caxiuanã, suggesting that nutrients are soon leached from várzea substrates once they no longer experience flooding and an influx of river sediments.

\section{4 | Below-ground taxonomic composition}

Alphaproteobacteria and Planctomycetes were abundant in our samples, accounting for $40 \%$ of our $16 \mathrm{~S}$ data (Figure 3a). These groups are known to be very diverse in undisturbed forests (de Carvalho et al., 2016), and they are generally common in Amazonian soils (Ritter, Zizka, et al., 2019; Zinger et al., 2019). Interestingly, several other bacterial groups commonly found globally (DelgadoBaquerizo et al., 2018) and even in Amazonian soils using the same primers than we used here (Ritter, Zizka, et al., 2019; Zinger et al., 2019)-notably Betaproteobacteria and Bacteroidetes-were not present in the Juruá samples. Because these groups are known to form a diverse range of habitats, including várzea and terra firme, this surprised us and clearly highlights that we have much to discover about Amazonian soil biodiversity.

Patescibacteria (e.g., the candidate phyla radiation group), not previously reported from other várzea soils, were found in the Juruá samples (Figure 3a). This group was recently described (Brown et al., 2015), and until now, it had only been registered in Amazonian pasture soils (Lemos et al., 2020). An interesting characteristic of Patescibacteria is the small size of their genomes (usually <1.5 Mbp) and their lack of biosynthetic capabilities (Brown et al., 2015). These characteristics indicate that they could be co-metabolic interdependent (He et al., 2015; Lemos et al., 2019). Such interdependencies with other organisms would suggest a restricted occurrence or a functionality that depends on the community in which they occur. Yet, Patescibacteria show similar functional profiles under distinct climate conditions (tropical soils and permafrost; Lemos et al., 2020). Although their apparent plasticity is interesting, very little information is available for this group. The design of new $16 \mathrm{~S}$ rRNA gene primers that better amplify Patescibacteria is required to elucidate the ecology and distribution of Patescibacteria in Amazonian soils and worldwide. Additionally, analysis of metatranscriptomes could improve our understanding of the metabolism in Patescibacteria and other bacteria under different substrate conditions.

Among the eukaryotes, we found a higher proportion of fungi in the Juruá substrates than previously documented elsewhere in Amazonia (Ritter, Zizka, et al., 2019). Whereas Ritter, Dunthorn, et al. (2020) found fewer fungi in várzea than in other environments, we found more fungi in várzea than in the adjacent terra firme, most of which were saprotrophs (Appendix S4: Figure A2). Singer et al. (1983) hypothesized that ectomycorrhizal fungi increase the ability of their host plants to acquire nutrients and water in low-fertility soils, such as in the Amazonian sandy-soil ecosystems. However, we found very few ectomycorrhizal fungi in both várzea (more fertile) and terra firme (less fertile; Appendix S4: Figure A2). Yet, around 35\% of the fungi could be not assigned to any functional guild. This makes comparisons difficult and highlights the need to further investigate Amazonian soil biodiversity and its ecology.

Some eukaryotic groups detected in other Amazonian localities with the same $18 \mathrm{~S}$ primers, as we used here (Ritter, Zizka, et al., 
2019; Zinger et al., 2019), were absent in the Juruá samples. Such groups include nematodes and arthropods (Figure $2 b$ ). Although the $18 \mathrm{~S}$ primers that we used are not optimal for sequencing metazoans, it was surprising not to find these groups in our samples (except for one nematode sequence in várzea and terra firme). Low nematode diversity in Amazonian várzeas was previously reported by Cares (1984). One reason for the absence of nematodes in várzea substrates could be the poor habitat suitability of várzea soil and litter given the high amounts of clay in the soil and the seasonal floods. However, this does not explain the absence of soil animals in our terra firme samples since these were relatively clay-free and unflooded. To test this hypothesis, we need further studies in soils with a gradual difference in clay proportion and specific primers targeting nematodes (Kawanobe et al., 2021) alongside morphological examination of the diversity in the samples.

\section{5 | CONCLUSION}

This is the first metabarcoding study to investigate the degree to which soil and litter biota are affected by the flooding gradient in Amazonian forests. In fact, as far as we are aware, substrates from only six other Amazonian várzeas have previously been investigated using a metabarcoding approach, and these studies did not consider the flooding gradient (Ritter, 2018; Ritter, Zizka, et al., 2019; Ritter, Faurby, et al., 2019). Hence, the DNA barcoding data hereinconsisting of a total of 19,550 ASVs, from 14 várzea and four terra firme plots-more than double the total database from Amazonian várzeas publicly available to date. Considering the extent of lowland Amazonian floodplain forests, $516,000 \mathrm{~km}^{2}$ (Hess et al., 2015), the need for more data from different geographical areas is patently clear

Studying below-ground communities along complex environmental gradients, like the one in the present study, offers an excellent opportunity to explore the responses of substrate biota to varying degrees of environmental stressors. These studies can further our understanding of the patterns in below-ground biodiversity, their roles in the dynamics of seasonally flooded forests, and how these communities might respond to anthropogenic pressure and climate change. Therefore, the characterization of below-ground biodiversity in flooded forests has theoretical implications for elucidating the patterns of biological diversity distribution. Practical implications include the identification of strategically important areas or areas of greater environmental sensitivity for the conservation of biological diversity in the face of environmental change. This is not trivial, as infrastructural development (e.g., hydroelectric dams) and climate change (more frequent extreme floods and droughts) are severely affecting the natural flood pulse and threatening the ecological integrity of seasonally flooded forests across Amazonia (Gloor et al., 2013; Junk et al., 2018; Latrubesse et al., 2020). Increased pressures in these ecosystems highlight the urgency for more studies of this kind to improve our understanding of biodiversity patterns and community structure, as these will allow us to better foresee and mitigate climate change impacts on ecosystem functions.

\section{ACKNOWLEDGEMENTS}

This publication is part of the Projeto Médio Juruá series on Resource Management in Amazonian Reserves (www.projetomed iojurua.org). We thank the Secretaria do Estado do Meio Ambiente e Desenvolvimento Sustentável do Amazonas (SEMA - DEMUC) and Instituto Brasileiro do Meio Ambiente e Recursos Naturais Renováveis (IBAMA)/Instituto Chico Mendes de Conservação da Biodiversidade (ICMBio) for authorizing the research $n^{\circ} 60 / 2016$ (RDS Uacari) and n55077-1 (RESEX Médio Juruá). We are grateful to the members from the Projeto Médio Juruá team for logistical support. We thank Rita Homem Pelicano for dedicated soil sampling in the field. We thank Michael J.G. Hopkins, Rafael Leandro de Assis, and Juliana Schietti with colleagues at INPA for providing logistical assistance and a place to work in Manaus. We thank Paulo Apóstolo Costa Lima Assunção (in memoriam) and Alexandro Elias dos Santos, assisted by Lorena M. Rincón, for identifying the woody plant species in the field and at the National Institute for Amazonia Research (INPA). We thank our local field assistants, Associação dos Produtores Rurais de Carauari (ASPROC), Operação Amazônia Nativa (OPAN), and the people of the central Juruá who in various ways assisted us throughout our work. Finally, we thank Heléne Aronson and Katarzyna Wojnicka at the University of Gothenburg for quantifying the sampled DNA. AA acknowledges financial support from the Swedish Research Council (2019-05191), the Swedish Foundation for Strategic Research (FFL15-0196) and the Royal Botanic Gardens, Kew. We thank the two anonymous reviewers and the editor for valuables suggestion on an earlier draft of this manuscript.

\section{CONFLICT OF INTEREST}

The authors declare that they have no known competing financial interests or personal relationships that could have appeared to influence the work reported in this paper.

\section{AUTHOR CONTRIBUTIONS}

CDR and YKB conceptualized this study; $A B S$ and $Y K B$ collected the data; CDR and LLH performed the data curation and formal analyses; CDR and YKB wrote the manuscript with the collaboration of AA, ABS, CAP, HRN, LLH, MD, and TH. All authors read and approved the final version of this manuscript.

\section{DATA AVAILABILITY STATEMENT}

All raw $16 \mathrm{~S}$ and $18 \mathrm{~S}$ sequences are available in GenBank under SubmissionID SUB9499732, BioProjectID PRJNA723037, samples accession SRR14286280 - SRR14286277. The ASV reads by sample and taxonomic affiliation are provided in the Appendix S1 (for 16S) and Appendix S2 (for 18S), and the script for analysis is available as Appendix S3.

\section{ORCID}

Micah Dunthorn (D) https://orcid.org/0000-0003-1376-4109

Henrik R. Nilsson (D) https://orcid.org/0000-0002-8052-0107

Camila D. Ritter (D) https://orcid.org/0000-0002-3371-7425 


\section{REFERENCES}

Adl, S. M., Simpson, A. G. B., Lane, C. E., Lukeš, J., Bass, D., Bowser, S. S., Brown, M. W., Burki, F., Dunthorn, M., Hampl, V., Heiss, A., Hoppenrath, M., Lara, E., le Gall, L., Lynn, D. H., McManus, H., Mitchell, E. A. D., Mozley-Stanridge, S. E., Parfrey, L. W., ... Spiegel, F. W. (2012). The revised classification of eukaryotes. Journal of Eukaryotic Microbiology, 59, 429-493. https://doi. org/10.1111/j.1550-7408.2012.00644.x

Akaike, H. (1974). A new look at the statistical model identification. EEE transactions on automatic control, 19(6), 716-723.

Alemán, L. A. B., Barbosa, R. I., Fernández, I. M., Carvalho, L. C. S., Barni, P. E., Oliveira, R. L. C., Vale Jr, J. F., \& Saravia Maldonado, S. A., \& Arriaga Pérez, N. E. (2019). Edaphic factors and flooding periodicity determining forest types in a topographic gradient in the Northern Brazilian Amazonia. International Journal of Plant \& Soil Science, 1-11.

Anderson, D. R. \& Burnham, K. P. (2004). Model selection and multimodel inference. Second. NY: Springer-Verlag, 63(2020),10.

Arias, M. E., Wittmann, F., Parolin, P., Murray-Hudson, M., \& Cochrane, T. A. (2018). Interactions between flooding and upland disturbance drives species diversity in large river floodplains. Hydrobiologia, 814, 5-17. https://doi.org/10.1007/s10750-016-2664-3

Assis, R. L., Haugaasen, T., Schöngart, J., Montero, J. C., Piedade, M. T. F., \& Wittmann, F. (2015b). Patterns of tree diversity and composition in Amazonian floodplain paleo-várzea forest. Journal of Vegetation Science, 26, 312-322. https://doi.org/10.1111/jvs.12229

Assis, R. L., Wittmann, F., Bredin, Y. K., Schöngart, J., Nobre Quesada, C. A., Piedade, M. T. F., \& Haugaasen, T. (2019). Above-ground woody biomass distribution in Amazonian floodplain forests: Effects of hydroperiod and substrate properties. Forest Ecology and Management, 432, 365-375. https://doi.org/10.1016/j.foreco.2018.09.031

Assis, R. L., Wittmann, F., Piedade, M. T. F., \& Haugaasen, T. (2015a). Effects of hydroperiod and substrate properties on tree alpha diversity and composition in Amazonian floodplain forests. Plant Ecology, 216, 41-54. https://doi.org/10.1007/s11258-014-0415-y

Auguie, B., \& Antonov, A. (2016). gridExtra: Miscellaneous functions for "grid" graphics (Version 2.2. 1) [Computer software].

Baker, T. R., Phillips, O. L., Malhi, Y., Almeida, S., Arroyo, L., Di Fiore, A., Erwin, T., Killeen, T. J., Laurance, S. G., Laurance, W. F., Lewis, S. L., Lloyd, J., Monteagudo, A., Neill, D. A., Patiño, S., Pitman, N. C. A., M. Silva, J. N., \& Vásquez Martínez, R. (2004). Variation in wood density determines spatial patterns in Amazonian forest biomass. Global Change Biology, 10, 545-562. https://doi. org/10.1111/j.1365-2486.2004.00751.x

Bardgett, R. D., \& Van Der Putten, W. H. (2014). Belowground biodiversity and ecosystem functioning. Nature, 515, 505-511. https://doi. org/10.1038/nature13855

Bennett, J. A., Maherali, H., Reinhart, K. O., Lekberg, Y., Hart, M. M., \& Klironomos, J. (2017). Plant-soil feedbacks and mycorrhizal type influence temperate forest population dynamics. Science, 355, 181184. https://doi.org/10.1126/science.aai8212

Bolker, B., \& Bolker, M. B. (2017). Package 'bbmle.' Tools Gen. Maximum Likelihood Estim. 641.

Bredin, Y. K., Hawes, J. E., Peres, C. A., \& Haugaasen, T. (2020). Structure and composition of Terra Firme and seasonally flooded Várzea forests in the Western Brazilian Amazon. Forests, 11, 1361. https://doi. org/10.3390/f11121361

Brown, C. T., Hug, L. A., Thomas, B. C., Sharon, I., Castelle, C. J., Singh, A., Wilkins, M. J., Wrighton, K. C., Williams, K. H., \& Banfield, J. F. (2015). Unusual biology across a group comprising more than $15 \%$ of domain Bacteria. Nature, 523, 208-211. https://doi.org/10.1038/ nature14486

Callahan, B. J., McMurdie, P. J., \& Holmes, S. P. (2017). Exact sequence variants should replace operational taxonomic units in marker-gene data analysis. ISME Journal, 11, 2639-2643. https:// doi.org/10.1038/ismej.2017.119

Callahan, B. J., McMurdie, P. J., Rosen, M. J., Han, A. W., Johnson, A. J. A., \& Holmes, S. P. (2016). DADA2: high-resolution sample inference from Illumina amplicon data. Nature Methods, 13, 581-583. https:// doi.org/10.1038/nmeth.3869

Cameron, E. K., Martins, I. S., Lavelle, P., Mathieu, J., Tedersoo, L., Bahram, M., Gottschall, F., Guerra, C. A., Hines, J., Patoine, G., Siebert, J., Winter, M., Cesarz, S., Ferlian, O., Kreft, H., Lovejoy, T. E., Montanarella, L., Orgiazzi, A., Pereira, H. M., ... Eisenhauer, N. (2019). Global mismatches in aboveground and belowground biodiversity. Conservation Biology, 33(5), 1187-1192. https://doi. org/10.1111/cobi.13311

Cameron, E. K., Martins, I. S., Lavelle, P., Mathieu, J., Tedersoo, L., Gottschall, F., Guerra, C. A., Hines, J., Patoine, G., Siebert, J., Winter, M., Cesarz, S., Delgado-Baquerizo, M., Ferlian, O., Fierer, N., Kreft, H., Lovejoy, T. E., Montanarella, L., Orgiazzi, A., ... Eisenhauer, N. (2018). Global gaps in soil biodiversity data. Nature Ecology \& Evolution, 2, 1042-1043. https://doi.org/10.1038/s4155 9-018-0573-8

Cares, J. E. (1984). Fauna fitonematologica de varzea e terra firme nas proximidades de Manaus-AM. UNB.

Carvalho, T. S., Jesus, E. D. C., Barlow, J., Gardner, T. A., Soares, I. C., Tiedje, J. M., \& Moreira, F. M. D. S. (2016). Land use intensification in the humid tropics increased both alpha and beta diversity of soil bacteria. Ecology, 97, 2760-2771. https://doi.org/10.1002/ ecy.1513

Castello, L., \& Macedo, M. N. (2016). Large-scale degradation of Amazonian freshwater ecosystems. Global Change Biology, 22, 9901007. https://doi.org/10.1111/gcb.13173

Crawley, M. J. (2007). Generalized linear models. The R book. $R$ B, pp. second, 511-526). New York: John Wiley \& Sons.

Delgado-Baquerizo, M., Oliverio, A. M., Brewer, T. E., BenaventGonzález, A., Eldridge, D. J., Bardgett, R. D., Maestre, F. T., Singh, B. K., \& Fierer, N. (2018). A global atlas of the dominant bacteria found in soil. Science, 359, 320-325. https://doi.org/10.1126/scien ce.aap9516

Delgado-Baquerizo, M., Reich, P. B., Trivedi, C., Eldridge, D. J., Abades, S., Alfaro, F. D., Bastida, F., Berhe, A. A., Cutler, N. A., Gallardo, A., García-Velázquez, L., Hart, S. C., Hayes, P. E., He, J.-Z., Hseu, Z.-Y., Hu, H.-W., Kirchmair, M., Neuhauser, S., Pérez, C. A., ... Singh, B. K. (2020). Multiple elements of soil biodiversity drive ecosystem functions across biomes. Nature Ecology \& Evolution, 4, 210-220. https://doi.org/10.1038/s41559-019-1084-y

Donagema, G. K., De Campos, D. B., Calderano, S. B., Teixeira, W. G., \& Viana, J. M. (2011). Manual de métodos de análise de solo. Brasilia: Embrapa Solos-Documentos.

Edwards, M. E., Alsos, I. G., Yoccoz, N., Coissac, E., Goslar, T., Gielly, L., Haile, J., Langdon, C. T., Tribsch, A., Binney, H. A., von Stedingk, H., \& Taberlet, P. (2018). Metabarcoding of modern soil DNA gives a highly local vegetation signal in Svalbard tundra. The Holocene, 28, 2006-2016. https://doi.org/10.1177/0959683618798095

Eisenhauer, N., Lanoue, A., Strecker, T., Scheu, S., Steinauer, K., Thakur, M. P., \& Mommer, L. (2017). Root biomass and exudates link plant diversity with soil bacterial and fungal biomass. Scientific Reports, 7, 1-8. https://doi.org/10.1038/srep44641

Ferlian, O., Cesarz, S., Craven, D., Hines, J., Barry, K. E., Bruelheide, H., Buscot, F., Haider, S., Heklau, H., Herrmann, S., Kühn, P., Pruschitzki, U., Schädler, M., Wagg, C., Weigelt, A., Wubet, T., \& Eisenhauer, N. (2018). Mycorrhiza in tree diversity-ecosystem function relationships: conceptual framework and experimental implementation. Ecosphere, 9, e02226. https://doi.org/10.1002/ecs2.2226

Gahan, J., \& Schmalenberger, A. (2014). The role of bacteria and mycorrhiza in plant sulfur supply. Frontiers in Plant Science, 5, 723. https:// doi.org/10.3389/fpls.2014.00723 
García-Palacios, P., Maestre, F. T., Kattge, J., \& Wall, D. H. (2013). Climate and litter quality differently modulate the effects of soil fauna on litter decomposition across biomes. Ecology Letters, 16, 1045-1053. https://doi.org/10.1111/ele.12137

Geisen, S., Mitchell, E. A. D., Adl, S., Bonkowski, M., Dunthorn, M., Ekelund, F., Fernández, L. D., Jousset, A., Krashevska, V., Singer, D., Spiegel, F. W., Walochnik, J., \& Lara, E. (2018). Soil protists: A fertile frontier in soil biology research. FEMS Microbiology Reviews, 42 , 293-323. https://doi.org/10.1093/femsre/fuy006

Geisen, S., Wall, D. H., \& van der Putten, W. H. (2019). Challenges and opportunities for soil biodiversity in the anthropocene. Current Biology, 29, R1036-R1044. https://doi.org/10.1016/j.cub.2019.08.007

Gloor, M., Brienen, R. J. W., Galbraith, D., Feldpausch, T. R., Schöngart, J., Guyot, J.-L., Espinoza, J. C., Lloyd, J., \& Phillips, O. L. (2013). Intensification of the Amazon hydrological cycle over the last two decades. Geophysical Research Letters, 40, 1729-1733. https://doi. org/10.1002/grl.50377

Guardiola, M., Uriz, M. J., Taberlet, P., Coissac, E., Wangensteen, O. S., \& Turon, X. (2015). Deep-sea, deep-sequencing: metabarcoding extracellular DNA from sediments of marine canyons. PLoS One, 10, e0139633. https://doi.org/10.1371/journal.pone.0139633

Haegeman, B., Hamelin, J., Moriarty, J., Neal, P., Dushoff, J., \& Weitz, J. S. (2013). Robust estimation of microbial diversity in theory and in practice. ISME Journal, 7, 1092. https://doi.org/10.1038/ ismej.2013.10

Hättenschwiler, S., \& Gasser, P. (2005). Soil animals alter plant litter diversity effects on decomposition. Proceedings of the National Academy of Sciences, 102, 1519-1524. https://doi.org/10.1073/ pnas. 0404977102

Haugaasen, T., \& Peres, C. A. (2006). Floristic, edaphic and structural characteristics of flooded and unflooded forests in the lower Rio Purús region of central Amazonia, Brazil. Acta Amazonica, 36, 25 35. https://doi.org/10.1590/S0044-59672006000100005

Hawes, J. E., \& Peres, C. A. (2016). Patterns of plant phenology in Amazonian seasonally flooded and unflooded forests. Biotropica, 48, 465-475. https://doi.org/10.1111/btp.12315

He, X., McLean, J. S., Edlund, A., Yooseph, S., Hall, A. P., Liu, S.-Y. Dorrestein, P. C., Esquenazi, E., Hunter, R. C., Cheng, G., Nelson, K. E., Lux, R., \& Shi, W. (2015). Cultivation of a human-associated TM7 phylotype reveals a reduced genome and epibiotic parasitic lifestyle. Proceedings of the National Academy of Sciences, 112, 244249. https://doi.org/10.1073/pnas.1419038112

Hess, L. L., Melack, J. M., Affonso, A. G., Barbosa, C., Gastil-Buhl, M., \& Novo, E. M. L. M. (2015). Wetlands of the lowland Amazon basin: Extent, vegetative cover, and dual-season inundated area as mapped with JERS-1 synthetic aperture radar. Wetlands, 35, 745756. https://doi.org/10.1007/s13157-015-0666-y

Higgins, M. A., Asner, G. P., Anderson, C. B., Martin, R. E., Knapp, D. E., Tupayachi, R., Perez, E., Elespuru, N., \& Alonso, A. (2015). Regionalscale drivers of forest structure and function in Northwestern Amazonia. PLoS One, 10, e0119887. https://doi.org/10.1371/journ al.pone. 0119887

Hillel, D. (2013). Fundamentals of soil physics. Academic press.

Johnson, N.C. (2010). Resource stoichiometryelucidates the structure and function of arbuscular mycorrhizas across scales. New Phytologist, 185, 631-647. https://doi.org/10.1111/j.1469-8137.2009.03110.x

Johnson, N. C., Gehring, C., \& Jansa, J. (2016). Mycorrhizal mediation of soil: fertility, structure, and carbon storage. Elsevier.

Julião, G. R., Venticinque, E. M., \& Fernandes, G. W. (2018). Influence of flood levels on the richness and abundance of galling insects associated with trees from seasonally flooded forests of Central Amazonia, Brazil. In R. W. Myster (ed.), Igapó (Black-water flooded forests) of the Amazon Basin (pp. 99-117). Cham: Springer.

Junk, W. (1989). Flood tolerance and tree distribution in central Amazonian floodplains. In: L. B. Holm-Nielsen, I. C. Nielsen, \& H.
Balslev (eds.),Tropical forests: Botanical dynamics, speciation and diversity. (pp. 47-64). Academic Press.

Junk, W. J., Piedade, M. T. F., da Cunha, C. N., Wittmann, F., \& Schöngart, J. (2018). Macrohabitat studies in large Brazilian floodplains to support sustainable development in the face of climate change. Ecohydrology \& Hydrobiology, 18, 334-344. https://doi. org/10.1016/j.ecohyd.2018.11.007

Junk, W. J., Piedade, M. T. F., Schöngart, J., \& Wittmann, F. (2012). A classification of major natural habitats of Amazonian white-water river floodplains (várzeas). Wetlands Ecology and Management, 20, 461-475. https://doi.org/10.1007/s11273-012-9268-0

Kassambara, A. \& Kassambara, M. A. (2020). Package 'ggpubr.' https:// cran.r-project.org/web/packages/ggpubr/index.html

Kawanobe, M., Toyota, K., \& Ritz, K. (2021). Development and application of a DNA metabarcoding method for comprehensive analysis of soil nematode communities. Applied Soil Ecology, 166, 103974. https://doi.org/10.1016/j.apsoil.2021.103974

Klindworth, A., Pruesse, E., Schweer, T., Peplies, J., Quast, C., Horn, M., \& Glöckner, F. O. (2013). Evaluation of general $16 \mathrm{~S}$ ribosomal RNA gene PCR primers for classical and next-generation sequencingbased diversity studies. Nucleic Acids Research, 41, e1. https://doi. org/10.1093/nar/gks808

Kubitzki, K. (1990). Themes of diversification in neotropical forest. Quimica Nova, 13, 4.

Latrubesse, E. M., d'Horta, F. M., Ribas, C. C., Wittmann, F., Zuanon, J., Park, E., Dunne, T., Arima, E. Y., \& Baker, P. A. (2020). Vulnerability of the biota in riverine and seasonally flooded habitats to damming of Amazonian rivers. Aquatic Conservation Marine and Freshwater Ecosystems, 31, 1136-1149.

Lemos, L. N., Manoharan, L., Mendes, L. W., Venturini, A. M., Pylro, V. S., \& Tsai, S. M. (2020). Metagenome assembled-genomes reveal similar functional profiles of CPR/Patescibacteria phyla in soils. Environmental Microbiology Reports, 12, 651-655.

Lemos, L. N., Medeiros, J. D., Dini-Andreote, F., Fernandes, G. R., Varani, A. M., Oliveira, G., \& Pylro, V. S. (2019). Genomic signatures and co-occurrence patterns of the ultra-small Saccharimonadia (phylum CPR/Patescibacteria) suggest a symbiotic lifestyle. Molecular Ecology, 28, 4259-4271. https://doi. org $/ 10.1111 / \mathrm{mec} .15208$

Love, M. I., Huber, W., \& Anders, S. (2014). Moderated estimation of fold change and dispersion for RNA-seq data with DESeq2. Genome Biology, 15, 550. https://doi.org/10.1186/s13059-014-0550-8

Mächler E., Walser J., Altermatt F. (2021). Decision-making and best practices for taxonomy-free environmental DNA metabarcoding in biomonitoring using Hill numbers. Molecular Ecology, 30(13), 33263339. http://dx.doi.org/10.1111/mec.15725

Maretti, C. C. (2014). Amazon: There is Hope! If we all do 'the right thing'...; Deforestation, Protected Areas and Indigenous Territories: Past, evolution and... Which future? Brasilia.

Martin, M. (2011). Cutadapt removes adapter sequences from highthroughput sequencing reads. Embnet. Journal, 17, 10-12. https:// doi.org/10.14806/ej.17.1.200

McMurdie, P. J., \& Holmes, S. (2013). phyloseq: an R package for reproducible interactive analysis and graphics of microbiome census data. PLoS One, 8, e61217. https://doi.org/10.1371/journ al.pone.0061217

McMurdie, P. J., \& Holmes, S. (2014). Waste not, want not: why rarefying microbiome data is inadmissible. PLoS Computational Biology, 10, e1003531. https://doi.org/10.1371/journal.pcbi.1003531

Moura, M. R., \& Jetz, W. (2021). Shortfalls and opportunities in terrestrial vertebrate species discovery. Nature Ecology \& Evolution, 5(5), 631-639. https://doi.org/10.1038/s41559-021-01411-5

Myster, R. W. (2016). The physical structure of forests in the Amazon Basin: a review. Botanical Review, 82, 407-427. https://doi. org/10.1007/s12229-016-9174-x 
Oksanen, J., Blanchet, F. G., Kindt, R., Legendre, P., McGlinn, D., Minchin, P. R., O'Hara, R. B., Simpson, G. L., Peter Solymos, M., Stevens, H. H., Szoecs, E., \& Wagner, H. (2010). Vegan: community ecology package. R package version 1.17-4. http//cran.r-project. org. Acesso em 23.

Parniske, M. (2008). Arbuscular mycorrhiza: the mother of plant root endosymbioses. Nature Reviews Microbiology, 6, 763-775. https://doi. org/10.1038/nrmicro1987

Parolin P., Wittmann F. (2010). Struggle in the flood: tree responses to flooding stress in four tropical floodplain systems. AoB PLANTS, 2010, plq003. http://dx.doi.org/10.1093/aobpla/plq003

Pereira, P., Bogunovic, I., Muñoz-Rojas, M., \& Brevik, E. C. (2018). Soil ecosystem services, sustainability, valuation and management. Current Opinion in Environmental Science \& Health, 5, 7-13. https:// doi.org/10.1016/j.coesh.2017.12.003

Petit, R. J., \& Hampe, A. (2006). Some evolutionary consequences of being a tree. Annual Review of Ecology Evolution and Systematics, 37, 187-214. https://doi.org/10.1146/annurev.ecols ys.37.091305.110215

Pietramellara, G., Ascher, J., Ceccherini, M. T., \& Renella, G. (2002). Soil as a biological system. Annals of Microbiology, 52, 119-132.

Põlme, S., Abarenkov, K., Henrik Nilsson, R., Lindahl, B. D., Clemmensen, K. E., Kauserud, H., Nguyen, N., Kjøller, R., Bates, S. T., Baldrian, P., Frøslev, T. G., Adojaan, K., Vizzini, A., Suija, A., Pfister, D., Baral, H.-O., Järv, H., Madrid, H., Nordén, J., ... Tedersoo, L. (2020). FungalTraits: a user-friendly traits database of fungi and fungus-like stramenopiles. Fungal Diversity, 105, 1-16. https://doi.org/10.1007/ s13225-020-00466-2

Prance, G. T. (1996). Islands in Amazonia. Philosophical Transactions of the Royal Society B: Biological Sciences, 351, 823-833.

Quast, C., Pruesse, E., Yilmaz, P., Gerken, J., Schweer, T., Yarza, P., Peplies, J., \& Glöckner, F. O. (2012). The SILVA ribosomal RNA gene database project: improved data processing and web-based tools. Nucleic Acids Research, 41, D590-D596. https://doi.org/10.1093/ nar/gks1219

R Core Team. (2020). R: The R project for statistical computing. 2019. https//www.r-project.org/ Accessed 2020-03-30

R Core Team 2021. R: A Language and Environment for Statistical Computing. https://www.r-project.org/

Ramalho, W. P., Andrade, M. S., de Matos, L. R. A., \& Vieira, L. J. S. (2016). Amphibians of varzea environments and floating meadows of the oxbow lakes of the Middle Purus River, Amazonas, Brazil. Biota Neotropica, 16(1). https://doi.org/10.1590/ 1676-0611-BN-2015-0093

Ritter, C. D., Dunthorn, M., Anslan, S., Xavier, V., Tedersoo, L., Henrik, R. \& Antonelli, A. (2020). advancing biodiversity assessments with environmental DNA: Long-read technologies help reveal the drivers of Amazonian fungal diversity. Ecology and Evolution 10, 75097524. https://doi.org/10.1002/ece3.6477

Ritter, C. D., Faurby, S., Bennett, D. J., Naka, L. N., ter Steege, H., Zizka, A., Haenel, Q., Nilsson, R. H., \& Antonelli, A. (2019). The pitfalls of biodiversity proxies: Differences in richness patterns of birds, trees and understudied diversity across Amazonia. Scientific Reports, 9. https://doi.org/10.1038/s41598-01955490-3

Ritter, C. D., Machado, A. F., Ribeiro, K. F., \& Dunthorn, M. (2020). Metabarcodingadvancesforecologyandbiogeographyof Neotropical protists: what do we know, where do we go? Biota Neotropica, 21(4). https://doi.org/10.1590/1676-0611-bn-2021-1214

Ritter, C. D., McCrate, G., Nilsson, R. H., Fearnside, P. M., Palme, U., \& Antonelli, A. (2017). Environmental impact assessment in Brazilian Amazonia: Challenges and prospects to assess biodiversity. Biological Conservation, 206, 161-168. https://doi.org/10.1016/j. biocon.2016.12.031

Ritter, C. D., Zizka, A., Barnes, C., Nilsson, R. H., Roger, F., \& Antonelli, A. (2019). Locality or habitat? Exploring predictors of biodiversity in Amazonia. Ecography, 42, 321-333. https://doi.org/10.1111/ ecog.03833

Ritter, C. D., Zizka, A., Roger, F., Tuomisto, H., Barnes, C., Nilsson, R. H., \& Antonelli, A. (2018). High-throughput metabarcoding reveals the effect of physicochemical soil properties on soil and litter biodiversity and community turnover across Amazonia. PeerJ, 2018, e5661. https://doi.org/10.7717/peerj.5661

Salovaara, K. J., Cárdenas, G. G., \& Tuomisto, H. (2004). Forest classification in an Amazonian rainforest landscape using pteridophytes as indicator species. Ecography (Cop.), 27, 689-700. https://doi. org/10.1111/j.0906-7590.2004.03958.x

Singer, R., Araujo, I., \& Ivory, M. H. (1983). The ectotrophically mycorrhizal fungi of the neotropical lowlands, especially central Amazonia. (Litter decomposition and ectomycorrhiza in Amazonian forests 2.). Beihefte zur Nov. hedwigia

Sombroek, W. (2000). Amazon landforms and soils in relation to biological diversity. Acta Amazonica, 30, 81. https://doi. org/10.1590/1809-43922000301100

Tang, Y., Horikoshi, M., \& Li, W. (2016). ggfortify: unified interface to visualize statistical results of popular $\mathrm{R}$ packages. The $R$ Journal, 8 , 474. https://doi.org/10.32614/RJ-2016-060

Targhetta, N., Kesselmeier, J., \& Wittmann, F. (2015). Effects of the hydroedaphic gradient on tree species composition and aboveground wood biomass of oligotrophic forest ecosystems in the central Amazon basin. Folia Geobot, 50, 185-205. https://doi.org/10.1007/ s12224-015-9225-9

Team, Q. D. (2015a). QGIS geographic information system. Open Source Geospatial Found. Proj. Versão 2.

Tedersoo, L., Bahram, M., Põlme, S., Kõljalg, U., Yorou, N. S., Wijesundera, R., Ruiz, L. V., Vasco-Palacios, A. M., Thu, P. Q., Suija, A., Smith, M. E., Sharp, C., Saluveer, E., Saitta, A., Rosas, M., Riit, T., Ratkowsky, D., Pritsch, K., Põldmaa, K., ... Abarenkov, K. (2014). Global diversity and geography of soil fungi. Science, 346, 1052-1053. https://doi. org/10.1126/science.aaa1185

Tedersoo, L., Bahram, M., \& Zobel, M. (2020). Plant-soil feedbacks and mycorrhizal type influence temperate forest population dynamics. Science, 367, eaba1223.

ter Steege, H., \& Hammond, D. S. (2001). Character convergence, diversity, and disturbance in tropical rain forest in Guyana. Ecology, 82, 3197-3212. https://doi.org/10.1890/00129658(2001)082<3197:CCDADI>2.0.CO;2

ter Steege, H., Pitman, N. C. A., Phillips, O. L., Chave, J., Sabatier, D., Duque, A., Molino, J.-F., Prévost, M.-F., Spichiger, R., Castellanos, H., von Hildebrand, P., \& Vásquez, R. (2006). Continental-scale patterns of canopy tree composition and function across Amazonia. Nature, 443, 444. https://doi.org/10.1038/nature05134

Terborgh, J., \& Andresen, E. (1998). The composition of Amazonian forests: patterns at local and regional scales. Journal of Tropical Ecology, 14, 645-664. https://doi.org/10.1017/S0266467498000455

Teste, F. P., Kardol, P., Turner, B. L., Wardle, D. A., Zemunik, G., Renton, M., \& Laliberté, E. (2017). Plant-soil feedback and the maintenance of diversity in Mediterranean-climate shrublands. Science, 355, 173-176. https://doi.org/10.1126/science.aai8291

Toledo, J. J., Castilho, C. V., Magnusson, W. E., \& Nascimento, H. E. M. (2017). Soil controls biomass and dynamics of an Amazonian forest through the shifting of species and traits. Brazilian Journal of Botany, 40, 451-461. https://doi.org/10.1007/s40415-016-0351-2

Van Der Heijden, M. G. A. (2002). Arbuscular mycorrhizal fungi as a determinant of plant diversity: in search of underlying mechanisms and general principles. In M. G. A. Heijden, \& I. R. Sanders (eds.), Mycorrhizal ecology (pp. 243-265). Springer.

Van Rossum, G., \& Drake, F. L. (2009). Python 3 References Manual. CreateSpace.

Wang, S., \& Ruan, H. (2008). Feedback mechanisms of soil biota to aboveground biology in terrestrial ecosystems. Biodiversity Science, 16, 407. https://doi.org/10.3724/SP.J.1003.2008.07356 
Wickham, H. (2016). ggplot2: elegant graphics for data analysis. Springer.

Wickham, H. (2017). tidyverse: Easily Install and Load "Tidyverse" Packages (Version R package version 1.1. 1).

Wittmann, F., Schöngart, J., \& Junk, W. J. (2010). Phytogeography, species diversity, community structure and dynamics of central Amazonian floodplain forests. In: W. Junk, M. Piedade, F. Wittmann, J. Schöngart, \& P. Parolin (Eds.), Amazonian floodplain forests (pp. 61-102). Springer.

Zinger, L., Taberlet, P., Schimann, H., Bonin, A., Boyer, F., De Barba, M., Gaucher, P., Gielly, L., Giguet-Covex, C., Iribar, A., RéjouMéchain, M., Rayé, G., Rioux, D., Schilling, V., Tymen, B., Viers, J., Zouiten, C., Thuiller, W., Coissac, E., \& Chave, J. (2019). Body size determines soil community assembly in a tropical forest. Molecular Ecology, 28, 528-543. https://doi.org/10.1111/ mec.14919

\section{SUPPORTING INFORMATION}

Additional supporting information may be found in the online version of the article at the publisher's website.

How to cite this article: Bredin, Y. K., Hess, L. L., Scabin, A. B., Dunthorn, M., Haugaasen, T., Peres, C. A., Nilsson, H. R., Antonelli, A., \& Ritter, C. D. (2021). Above- and below-ground biodiversity responses to the prolonged flood pulse in central-western Amazonia, Brazil. Environmental DNA, 00, 1-16. https://doi.org/10.1002/edn3.268 